\title{
PENYUSUNAN SISTEM BASIS DATA POHON KOTA \\ (Studi Kasus Jakarta Barat)
}

Oleh :

MUHAMMAD RIZKI

A44053441

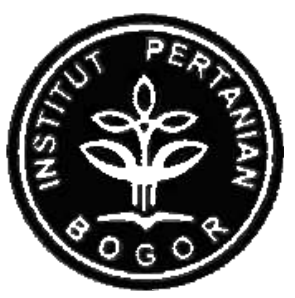

\section{DEPARTEMEN ARSITEKTUR LANSKAP}

FAKULTAS PERTANIAN

INSTITUT PERTANIAN BOGOR 


\section{RINGKASAN}

\section{MUHAMMAD RIZKI, Penyusunan Sistem Basis Data Pohon Jakarta Barat (studi kasus Jakarta Barat). Di bawah bimbingan BAMBANG SULISTYANTARA.}

Jalan merupakan jalur pergerakan orang, kendaraan serta sebagai tempat beraktifitas, seperti bekerja, berdagang, belajar, dan lain-lain. Jalan Palmerah Utara dan jalan S Parman merupakan jalan kolektor dan arteri yang memiliki lalu lintas yang padat, dimana pada sepanjang jalannya terdapat pohon-pohon yang berguna untuk memberikan kenyamanan bagi pengguna jalan. Namun keberadaan pohon di sepanjang jalan juga akan memberikan masalah, misalnya pohon tumbang dan ini akan membahayakan bagi pengguna jalan. Dengan demikian diperlukan pengelolaan dan pemeliharaan yang baik, yang salah satunya adalah monitoring dan menyusun data inventarisasi pohon.

Dinas Pertamanan dan Pemakaman kota Jakarta yang bertanggung jawab atas pengelolaan fasilitas pertamanan kota selama ini melakukan pengelolaan data inventarisasi pohon secara manual. Cara seperti ini menyebabkan pengelola membutuhkan waktu yang cukup lama dan biaya yang cukup besar dalam pemutakhiran data inventarisasi pohon. Oleh karena itu diperlukan pendataan pohon secara dijital untuk mengefisienkan kegiatan untuk pengelolaan pohon teesebut. Pembuatan program basis data menggunkan 3 software yaitu Macromedia Dreamweaver 8 sebagai GUI Php, Google Map, dan MySQL.

Penyusunan basis data pohon untuk pembuatan tampilan manggunakan bahasa pemrograman Php dengan Macromedia Dreamweaver 8 sebagai alat bantu GUI, sedangkan untuk penyimpanan data atribut menggunakan MySQL, dan untuk menampilkan lokasi pohon secara spasial digunakan Google Map yang dikoneksikan ke dalam aplikasi menggunakan Google Map API key.

Tampilan akhir aplikasi basis data ini berupa aplikasi web, sehingga untuk menjalankan aplikasi ini dibutuhkan web browser dan koneksi internet. Untuk penggunaan lebih lanjut aplikasi ini dapat di-hosting dan digunakan secara online.

Pada pembuatan aplikasi ini masih terdapat kekurangan pada sistem keamanan. Untuk coding dan desain interface aplikasi dapat terus dikembangkan agar menjadi lebih baik lagi. 


\title{
PENYUSUNAN SISTEM BASIS DATA POHON KOTA (Studi Kasus Jakarta Barat)
}

Oleh :

MUHAMMAD RIZKI

A44053441

Skripsi

sebagai salah satu syarat untuk memperoleh gelar

Sarjana Pertanian pada

Departemen Arsitektur Lanskap

\author{
DEPARTEMEN ARSITEKTUR LANSKAP \\ FAKULTAS PERTANIAN \\ INSTITUT PERTANIAN BOGOR




\title{
LEMBAR PENGESAHAN
}

\author{
Judul Penelitian $\quad$ : Penyusunan Sistem Basis Data Pohon Kota (Studi \\ Kasus Jakarta Barat) \\ Nama Mahasiswa : Muhammad Rizki \\ NIM : $\quad$ A44053441 \\ Departemen : : Arsitektur Lanskap \\ Disetujui : \\ Dosen Pembimbing
}

Dr. Ir. Bambang Sulistyantara, MAgr.

NIP : 196010221986011001

Mengetahui :

Ketua Departemen Arsitektur Lanskap

Tanggal Disetujui :

Dr. Ir. Siti Nurisjah, MSLA

NIP : 194809121974122001 


\section{LEMBAR PERNYATAAN}

Dengan ini saya menyatakan bahwa skripsi Penyusunan Sistem Basis Data Pohon Kota (Studi Kasus Jakarta Barat) adalah karya saya sendiri dan belum diajukan dalam bentuk apa pun kepada perguruan tinggi mana pun. Sumber informasi yang berasal atau dikutip dari karya yang diterbitkan maupun tidak diterbitkan dari penulis lain telah disebutkan dalam teks dan dicantumkan dalam Daftar Pustaka di bagian akhir skripsi ini.

Bogor, Januari 2011

Muhammad Rizki

NRP A44053441 


\section{RIWAYAT HIDUP}

Penulis mempunyai nama lengkap Muhammad Rizki, dilahirkan di Jakarta pada tanggal 13 Juli 1987. Penulis merupakan anak pertama dari dua bersaudara yang dilahirkan oleh pasangan Bapak Edison Mustafa dan Ibu Iwarnis. Penulis menyelesaikan jenjang pendidikan dasarnya di Sekolah Dasar Negeri Komplek Kota Legenda Bekasi Timur pada tahun 1999. Kemudian pada tahun 1999 melanjutkan jenjang pendidikannya di SLTPN 88 di Jakarta Barat. Tiga tahun kemudian penulis melanjutkan jenjang pendidikan menengah di Sekolah Menengah Umum (SMU) 16 Jakarta Barat.

Pada tahun 2005 setelah lulus dari SMU, penulis berhasil memasuki Institut Pertanian Bogor (IPB) melalui jalur Seleksi Penerimaan Mahasiswa Baru (SPMB). Setelah menyelesaikan tahap Tingkat Persiapan Bersama (TPB) di tahun pertama, penulis diterima di Departemen Arsitektur Lanskap. Di departemen ini penulis aktif di kegiatan keorganisasian Himpunan Profesi (HIMPRO) Himpunan Mahasiswa Arsitektur Lanskap (HIMASKAP). Dalam kepengurusan HIMASKAP, penulis tercatat pernah menjadi anggota Bagian Infokom HIMASKAP 2008. 


\section{KATA PENGANTAR}

Puji syukur kehadirat Allah SWT atas limpahan rahmat, hidayah, serta karunia-Nya sehingga penulis dapat menyelesaikan skripsi yang berjudul

“Penyusunan Sistem Basis Data Pohon Kota (Studi Kasus Jakarta Barat". Ucapan terima kasih penulis sampaikan kepada;

1. Orangtua, Drs. Edison Mustafa dan Iwarnis., dan Adikku Fikriza Aziz yang telah memberikan dukungan moral dan doa selama ini kepada penulis.

2. Dr. Ir. Bambang Sulistyantara MAgr. selaku Dosen Pembimbing Skripsi atas bimbingan dan pengarahan dalam pembuatan skripsi ini.

3. Dr. Andi Gunawan MSc. selaku pembimbing akademik, terima kasih atas perhatian yang telah diberikan.

4. Dr. Ir. Siti Nurisjah, MSLA selaku Ketua Departemen Arsitektur Lanskap.

5. Teman-teman seperjuangan di ARL 42, terima kasih atas segala bantuan dan kerjasamanya selama menuntut ilmu di IPB semoga kita semua menjadi orang sukses.

6. Anjar Purnama terima kasih atas bantuannya.

7. Kartika Sari Hanafri terima kasih atas dukungannya

8. Agung Ramadhan terima kasih telah menemani survey lapang.

9. Adik-adik dan kakak-kakak angkatan di ARL 37, 38, 39, 40, 41, 43, 44, 45, dan 46, terima kasih atas inspirasi yang telah diberikan.

10. Teman-teman Republik Gonggo terima kasih telah menemani selama kuliah dan pembuatan skripsi, semoga kita semua menjadi orang sukses.

11. Teman-teman Republik Galih terima kasih telah menemani selama kuliah dan pembuatan skripsi, semoga kita semua menjadi orang sukses.

12. Seluruh pihak yang tidak dapat saya sebutkan satu persatu, terima kasih atas bantuan yang telah diberikan, semoga amalnya mendapat balasan dari Allah SWT. 
Penulis terbuka dan menyambut dengan baik atas segala kritik dan saran demi kelancaran dan kesempurnaan penyelesaian penelitian ini.

Bogor, Januari 2011 


\section{DAFTAR ISI}

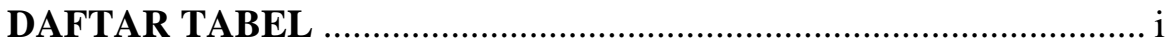

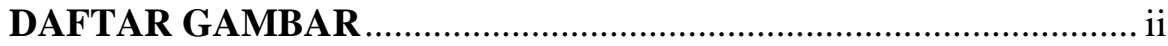

DAFTAR LAMPIRAN ................................................................... ii

PENDAHULUAN

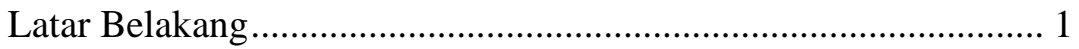

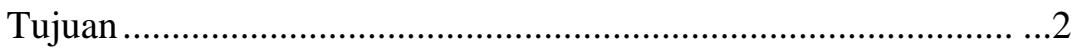

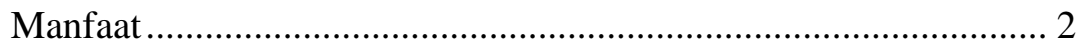

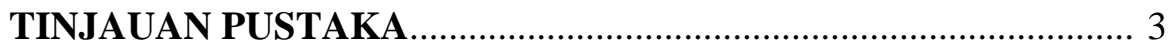

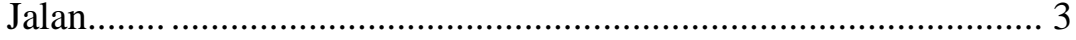

Fungsi Pohon pada Lanskap Jalan................................................. 3

Karakter Pohon pada Lanskap Jalan................................................ 4

Pemeliharaan Lanskap .................................................................. 5

Basis Data dan Sistem Manajemen Basis Data................................. 5

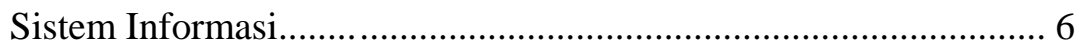

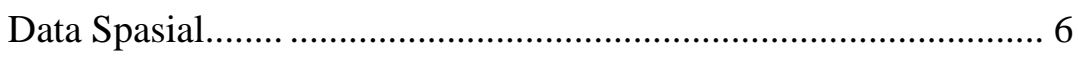

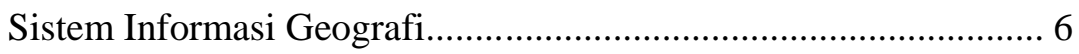

Perangkat lunak MySQL.......................................................... 7

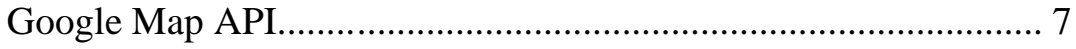

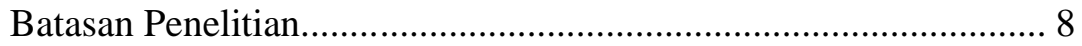

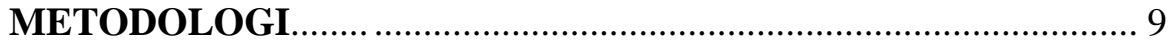

Waktu dan lokasi pengambilan data............................................. 9

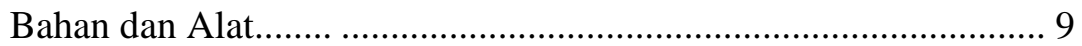

Pengumpulan Data Pohon di Lapang......................................... 10

Pemetaan Data Pohon................................................................... 16

Pengolahan Basis Data Pohon .................................................... 16

Penyajian Hasil.......................................................................... 16

HASIL DAN PEMBAHASAN....................................................... 17

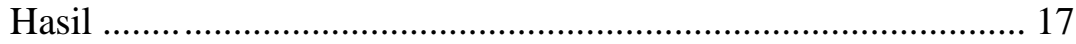

Pengambilan Data Pohon................................................... 17

Pengelolaan Data Gambar.................................................. 17 
Pengelolaan Data Peta......................................................... 17

Pembuatan Program Aplikasi.............................................. 18

Pemasukkan Data Pohon........................................................ 30

Penggunaan Aplikasi Basis Data Pohon............................ 30

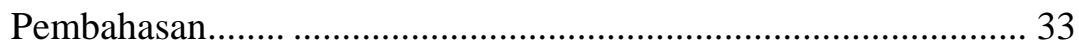

Inventarisasi Pohon dalam MySQL,Php, dan Google Map...32

Inventarisasi Pohon untuk Instansi...................................... 37

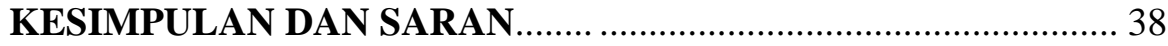

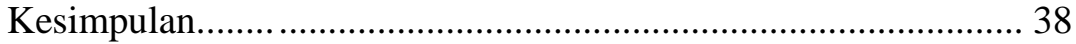

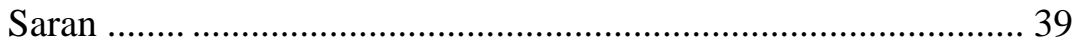

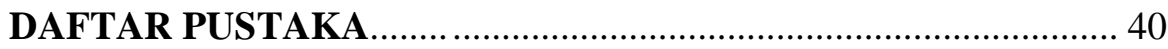

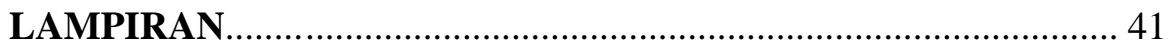




\title{
DAFTAR TABEL
}

\author{
Tabel 1. Kategori kelas DBH pohon ....................................................... 9 \\ Tabel 2. Kelas tinggi pohon berdasarkan barakteristiknya ...................... 10 \\ Tabel 3. Kelas lebar tajuk................................................................... 10 \\ Tabel 4. Kerusakan hama dan penyakit pada pangkal akar dan batang.. 11 \\ Tabel 5. Kerusakan hama dan penyakit pada pangkal cabang dan daun 12 \\ Tabel 6. Tingkat kerusakan hama dan penyakit pada pohon .................. 13 \\ Tabel 7. Kerusakan mekanik pada pohon ............................................... 13 \\ Tabel 8. Tingkat kerusakan mekanik .................................................. 14
}

Halaman 


\section{DAFTAR GAMBAR}

\section{Halaman}

Gambar 1. Peta Lokasi Penelitian ...................................................... 9

Gambar 2. Skema Pembuatan Aplikasi.................................................. 18

Gambar 3. Mengaktifkan MySQL Melalui Xampp 1.6 ........................ 20

Gambar 4. Tampilan Home MySQL ................................................... 20

Gambar 5. Tampilan Menu Create Table ............................................. 21

Gambar 6. Tampilan Menu Create Field .............................................. 22

Gambar 7. Tampilan Hasil Field pada Tabel Data_atribut_pohon ....... 22

Gambar 8. Tampilan Hasil Field pada Tabel Password ....................... 22

Gambar 9. Tampilan Halaman Home Sebelum Login .......................... 24

Gambar 10. Tampilan Halaman Home Setelah Login ........................... 24

Gambar 11. Tampilan Halaman Login .................................................. 25

Gambar 12. Tampilan Halaman Input Data ......................................... 26

Gambar 13. Tampilan Halaman Input Data lanjutan .............................. 26

Gambar 14. Tampilan Halaman Detail .................................................. 27

Gambar 15. Tampilan Halaman Detail Lanjutan Sebelum Login .......... 27

Gambar 16. Tampilan Halaman Detail Lanjutan Setelah Login ............ 28

Gambar 17. Tampilan Halaman Map View Mode Hybrid .................... 29

Gambar 18. Tampilan Halaman Help .................................................. 29

Gambar 19. Tampilan Skema Penggunaan Aplikasi ............................. 32

Gambar 20. Tampilan Skema Proses Spasial......................................... 35

Gambar 21. Foto Salah Satu Pohon di Jalan S Parman........................... 36

Gambar 22. Foto Salah Satu Pohon di Jalan Palmerah Utara ................. 36 


\section{DAFTAR LAMPIRAN}

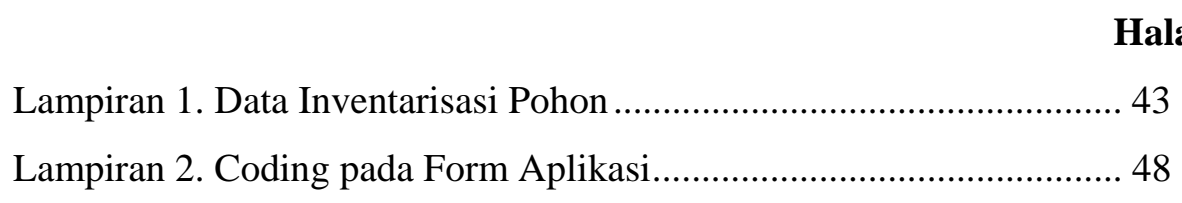




\section{PENDAHULUAN}

\section{Latar Belakang}

Jalan merupakan bagian yang sangat penting dalam lanskap perkotaan. Jalan adalah jalur yang dapat menghubungkan transportasi dari satu tempat ke tempat lainnya. Untuk itu kenyamanan dan keamanan pada jalan-jalan perkotaan juga sangat penting untuk mendukung mobilitas masyarakatnya. Pohon peneduh merupakan salah satu sarana penunjang yang dapat memberikan kenyamanan bagi pengguna jalan dan juga memberikan jasa lingkungan lainnya. Selain memberikan manfaat, pohon peneduh juga dapat memberikan masalah antara lain; apabila tumbang, apabila pohon tersebut merupakan jenis yang dapat memberikan efek alergi pada manusia, dan sebagainya.

Dengan adanya manfaat dan juga resiko masalah yag dapat ditimbulkan maka pohon peneduh pada jalan perkotaan harus dikelola dengan baik. Salah satu tahapan pengelolaan pohon adalah inventarisasi pohon untuk mendapatkan data mengenai deskripsi, lokasi, jumlah, dan kesehatan pohon. Proses inventarisasi juga akan membantu dalam menyiapkan pendanaan yang dibutuhkan untuk melakukan perawatan RTH.

Selama ini data inventarisasi dikelola secara manual sehingga apabila terjadi perubahan kondisi di lapang proses pambaruan basis data manjadi lambat, padahal perubahan kondisi dikarenakan proses alam maupun hasil perencanaan pihak pengelola bisa terjadi dengan cepat. Untuk itu diperlukan pemanfaatan teknologi komputer dengan melakukan penyusunan basis data spasial.

Sistem basis data spasial adalah suatu model realitas yang merupakan inti atau pusat dari Sistem Informasi Geografis (SIG). Sedangkan Sistem Informasi Geografis (SIG) itu sendiri merupakan suatu alat yang dapat digunakan untuk mengelola (input, manajemen, proses, dan output) data spasial atau data yang bereferensi geografis. Setiap data yang merujuk lokasi di permukaan bumi dapat disebut sebagai data spasial bereferensi geografis. Seperti halnya dengan data-data yang berkaitan dengan salah satu aspek tata hijau perkotaan yaitu pohon kota.

Salah satu upaya untuk mengelola data dan informasi inventarisasi pohon kota tersebut yaitu dengan melakukan pemanfaatan serta pendekatan suatu sistem teknologi berbasiskan Sistem Informasi Geografis (SIG). Sistem ini sangat efisien 
dan efektif dalam kegiatan analisis karena SIG mampu membantu melakukan interpretasi terhadap lingkungan. Sistem Informasi Geografis (SIG) sebagai suatu sistem berbasis komputer dengan empat kemampuan untuk menangani data bereferensi geografis, yaitu: pemasukan, pengelolaan atau manajemen data (penyimpanan dan pengaktifan kembali), manipulasi dan analisis, serta keluaran.

Dengan menggunakan basis data yang disusun berdasarkan pendekatan SIG ini, data inventarisasi pohon dapat diwujudkan dalam bentuk tabulasi data serta dalam bentuk spasial atau peta yang interaktif, kemudian disajikan dengan media penyaji (user interface) yang mudah digunakan sehingga data dan informasi yang terkandung didalamnya dapat dimanfaatkan dan dianalisis secara cepat dan tepat sesuai dengan hasil yang diharapkan.

Masalah yang terjadi terhadap inventarisasi pohon kota adalah mengenai jenis pohon kota tersebut dan juga kondisinya yang dapat berubah sehingga mempengaruhi pengelolaan data-data spasial yang telah dikumpulkan.

Masalah tersebut yang akan dijadikan dasar dalam penyusunan tugas akhir ini, yaitu menyusun basis data spasial pohon kota di daerah Jakarta Barat melalui pendekatan Sistem Informasi Geografis (SIG).

\section{Tujuan}

Menyusun aplikasi basis data yang dapat menyimpan data spasial inventarisasi pohon kota Jakarta Barat agar data tersebut dapat dikelola dengan mudah, terjamin keakuratannya, efektif dalam penyimpanan, serta mudah untuk di akses kembali sebagai data pendukung untuk melakukan pengelolaan pohon kota.

\section{Manfaat}

1. Mengatasi hambatan-hambatan dalam pengelolaan data inventarisasi

2. Digunakan sebagai data pendukung dalam penegelolaan pohon kota

3. Sebagai informasi ilmiah 


\title{
TINJAUAN PUSTAKA
}

\begin{abstract}
Jalan
Menurut Simonds (1978), bahwa dalam lanskap kehidupan manusia tesusun oleh tempat dan jalan, dimana jalan berfungsi sebagai jalur pergerakan orang, kendaraan serta sebagai pusat aktivitas. Jalan itu sendiri merupakan suatu kesatuan sistem jaringan yang mengikat dan menghubungkan pusat-pusat kota dan wilayah yang termasuk dalam pengaruh pelayanannya dalam satu hubungan hirarki (Dirjen Bina Marga, 1980).

Disebutkan pada Undang-Undang No.13 tahun 1980 bahwa jalan adalah suatu prasana perhubungan darat, meliputi segala bagian jalan termasuk bangunan pelengkap dan perlengkapannya yang diperuntukkan bagi lalu lintas. Bagian jalan menurut PP No.26 tahun 1985 meliputi:
\end{abstract}

1. Daerah manfaat jalan meliputi badan jalan, tepi jalan, dan ambang pengamannya.

- Badan jalan, yaitu jalur lalu lintas dengan atau tanpa median.

- Saluran tepi jalan, merupakan saluran penampungan dan penyaluran air, agar badan jalan bebas dari pengaruh air.

- Ambang pengaman, yaitu bagian yang terletak paling luar dari daerah pemanfaatan jalan untuk mengamankan bangunan jalan.

2. Daerah milik jalan meliputi daerah manfaat jalan dan sejalur tanah tertentu di luar daerah manfaat jalan untuk pelebaran dikemudian hari.

3. Daerah pengawasan jalan merupakan jalur lahan tertentu di luar daerah milik jalan yang diawasi Pembina jalan agar tidak mengganggu pandangan pengemudi dan kontruksi bangunan jalan.

\section{Fungsi Pohon pada Lanskap Jalan}

Pohon adalah tanaman tahunan berkayu dan berbatang tinggi dengan dahan dan ranting jauh di atas permukaan tanah (Dirjen Bina Marga, 1999). Pada dasarnya penggunaan jenis pohon pada lanskap jalan harus disesuaikan dengan desain lanskap jalan yang bersangkutan serta fungsi pohon yang diharapkan. Secara umum pohon yang ditanam di tepi jalan diharapkan dapat memberikan beberapa fungsi, antara lain sebagai: (1) Pengarah dan panduan keselamatan 
pengguna jalan; (2) Pengendali iklim setempat; (3) Pemasok sumber oksigen; (4) Penyimpan air yang masuk ke dalam tanah; (5) Pencegah erosi tanah; (6) Penyetimbang lingkungan dan ekologi: mengurangi kebisingan, menyaring polutan, menahan angin kencang, mengurangi tekanan hujan besar, menahan sialunya pantulan sinar matahari; (7) Habitat bagi satwa liar; (8) Saran pendidikan bagi masyarakat untuk lebih memperhatikan lingkungan hidup (Pemerintah Kota Bogor, 2003).

\section{Karakter Pohon pada Lanskap Jalan}

Dari segi struktur pohon, beberapa karakternya perlu diperhatikan dalam pemilihan jenis pohon untuk lanskap jalan. Pemerintah Kota Bogor dan Fakultas Pertanian IPB (2003), dalam penelitiannya menyatakan bahwa karakter pohon yang berpengaruh terhadap tujuan penanaman pohon pada lanskap jalan, antara lain: (1) Akar harus cukup kuat untuk menahan getaran yang disebabkan lajunya kendaraan. Jenis pohon yang tidak mempunyai bentuk akar yang menembus permukaan aspal dan beton disarankan dalam penanaman pohon kasus ini; (2) Bentuk tajuk, yang akan member efek naungan di mana hal ini berhubungan dengan penetrasi radiasi matahari sehingga temperature udara di sekitar jalan menjadi turun; tajuk yang terlalu rapat juga kurang baik karena akan menutupi badan jalan; (3) Batang dan percabangan pohon dipilih yang elastic serta kuat untuk menghindari roboh atau rusaknya pohon apabila bertiup angin yang kencang; (4) Daun tidak mudah gugur untuk menghindari pemeliharaan penyapuan jalan yang intensif; (5) Buah pohon jalan hendaknya tidak yang besar dan keras; buah yang besar dan keras akan membahayakan pengguna jalan bila rontok; (6) Tidak mudah terserang hama dan penyakit; (7) Penampilan keseluruhan pohon yang indah akan member nilai visual yang indah terhadap lanskap jalan; (8) Daya adaptasi yang tinggi, diperlukan bagi pohon jalan terutama yang ditanam pada jalan dengan tekanan lingkungan yang tinggi akibat pencemaran udara, sempitnya media jalan atau pada median bertrotoar; (9) Tingkat pemeliharaan yang rendah bagi pohon yang ditanam di lanskap jalan akan jauh lebih sesuai dengan tingkat pemeliharaan yang tinggi. 


\section{Pemeliharaan Lanskap}

Kegiatan pemeliharaan suatu lanskap dilaksanakn untuk memperjelas tujuan agar tanaman berada dalam keadaan sehat dan menarik, selain itu pemeliharaan juga bertujuan untuk menjaga lanskap agar tetap bersih, nyaman, aman. Pemeliharaan bertujuan untuk menjaga dan merawat areal lanskap dengan segala fasilitas yang berada di dalamnya agar kondisinya tetap baok dan sebisa mungkin mempertahankan keadaan yang sesuai tujuan rancangan atau desain semula (Arifin dan Arifin, 1999).

Carpenter, Walker, Lanphear (1975), menekankan hal yang penting dalam pemeliharaan lanskap yaitu pekerjaan yang tepat harus dikerjakan dalam waktu yang tepat, oleh sebab itu dibutuhkan jadwal pemeliharaan. Jadwal tersebut dibuat dan dikembangkan melalui empat tahap, yaitu:

- Mengklasifikasi tapak menurut peringkat pemeliharaan

- Membaca daftar nama tanaman

- Menentukan jenis pekerjaan yang dibutuhkan

- Menyusun langkah-langkah pekerjaan yang harus dilakukan

Pembuatan jadwal sangat berguna untuk mengetahui apakah pekerjaan pemeliharaan dilaksanakan sesuai dengan waktu yang telah ditentukan. Data inventarisasi dijital dapat membantu tahapan pemeliharaan tersebut.

\section{Basis Data dan Sistem Manajemen Basis Data (DBMS)}

Basis data (database) merupakan sekumpulan data-data yang saling berhubungan antara satu dengan yang lain yang disimpan dalam perangkat keras komputer dan akan diolah dengan perangkat lunak. Basis data sendiri adalah kumpulan berkas-berkas yang saling berhubungan sehingga membentuk suatu bangunan data (Aziz dan Pujiono, 2006)

Sebuah sistem manajemen basis data adalah sebuah program komputer (atau secara lebih tipikal adalah seperangkat program komputer) yang didisain untuk mengatur/memanajemen sebuah basis data sebagai sekumpulan data yang disimpan secara terstruktur, dan melakukan operasi-operasi atas data atas permintaan penggunanya (Aziz dan Pujiono, 2006). 


\section{Sistem Informasi}

Sistem informasi merupakan kumpulan dari perangkat keras, perangkat lunak serta manusia yang aakan mengolah data menggunakan perangkat tersebut. Manusia terdiri dari end user dan information system specialist . Perangkat keras terdiri dari sistem, informasi, program dan prosedur. Sedangkan data terdiri atas data itu sendiri.

Data diperoleh dari sumber data. Data kemudian ditransformasikan oleh aktifitas pengolahan informasi menjadi berbagai macam informasi yang dibutuhkan oleh end user. Pengolahan informasi terdiri atas input, proses, output dan kontrol (Aziz dan Pujiono, 2006).

\section{Data Spasial}

Data spasial adalah data yang memiliki referensi ruang kebumian (georeference) dimana berbagai data atribut terletak dalam berbagai unit spasial. Sekarang ini data spasial menjadi media penting untuk perencanaan pembangunan dan pengelolaan sumber daya alam yang berkelanjutan pada cakupan wilayah continental, nasional, regional maupun lokal (Aziz dan Pujiono, 2006).

\section{Sistem Informasi Geografi}

Sistem Informasi Geografi adalah sebuah sistem yang meyajikan informasi dalam bentuk grafis dengan menggunakan peta sebagai antar muka dengan fungsi untik menyimpan dan memanipulasi data geografis (Aziz dan Pujiono, 2006). Dan Environmental Sistem Research Institute (ESRI) menyatakan bahwa Sistem Informasi Geografi adalah alat yang berbasis komputer untuk memetakan dan menganalisa sesuatu yang terjadi di bumi. Komponen dari Sistem Informasi Geografi terdiri atas perangkat keras (hardware), perangkat lunak (software), data, manusia dan metode.

Perangkat keras dari Sistem Informasi Geografi terdiri atas perangkat untuk mengambil data (scanner, digitizer, dan lain-lain), menyimpan dan memanggil data, dan perangkat untuk megeluarkan data yang telah ditransformasikan dan dimanipulasi (layar, printer dan lain-lain). Perangkat lunak dari sistem ini adalah yang memiliki kemampuan untuk memanipulasi dan menganalisa data spasial, secara umum memiliki lima komponen, yaitu : 
1. Perangkat untuk import data

2. Basis data

3. Sistem basis data

4. Perangkat untuk mentransfer dan memanipulasi data

5. Perangkat untuk menyajikan dan mencetak data

Sistem Informasi Geografi dalam pengolahan informasi yang ada berkaitan erat dengan perangkat-perangkat sistem informasi lainnya seperti desktop mapping, remote sensing, CAD, GPS, Data Base Management Sistem (DBMS). Secara umum proses dalam Sistem Informasi Geografi adalah sebagai berikut :

1. Input

2. Manipulasi

3. Manajemen

4. Query dan analisis

5. Visualisasi

\section{Perangkat lunak MySQL}

Menurut Abdul Kadir (2009) MySQL adalah sebuah implementasi dari Sistem Manajemen Basis Data Relasional ( $\underline{\text { RDBMS }}$ ) yang didistribusikan secara gratis dibawah lisensi GPL (General Public License). Setiap pengguna dapat secara bebas menggunakan MySQL, namun dengan batasan perangkat lunak tersebut tidak boleh dijadikan produk turunan yang bersifat komersial. MySQL sebenarnya merupakan turunan salah satu konsep utama dalam basisdata yang telah ada sebelumnya; SQL (Structured Query Language). SQL adalah sebuah konsep pengoperasian basisdata, terutama untuk pemilihan atau seleksi dan pemasukan data, yang memungkinkan pengoperasian data dikerjakan dengan mudah secara otomatis.

\section{Google Map API}

Google Map adalah sebuah jasa peta globe virtual gratis dan online disediakan oleh Google dapat ditemukan di http://maps.google.com. Jasa tersebut menawarkan peta yang dapat diseret dan gambar satelit untuk seluruh dunia. 
Google Map API adalah alat untuk mengintegrasikan Google Map ke dalam aplikasi lain dengan menggunakan data point dari aplikasi tersebut (Amri Shodiq, 2009).

\section{Batasan Penelitian}

Sistem basis data ini disusun berdasarkan data-data dan informasi yang diperoleh mengenai daerah Jakarta Barat, khususnya yang berkenaan dengan inventarisasi pohon kota. Mengingat luasnya permasalahan mengenai tata hijau dan pohon kota, maka penelitian ini dibatasi pada beberapa ruas jalan sebagai studi kasus, yaitu jalan Palmerah Utara dan jalan S Parman segmen Jembatan Slipi sampai Slipi Jaya. 


\section{METODOLOGI}

\section{Waktu dan Lokasi Pengambilan Data}

Pelaksanaan kegiatan studi ini dilakukan di wilayah Kotamadya Jakarta Barat pada bulan Mei 2010. Lokasi studi memiliki posisi geografi $106^{\circ}-48^{\circ} \mathrm{BT}$ dan $60^{\circ}-12^{\circ}$ LU dengan luas wilayah $127,11 \mathrm{~km}^{2}$.

Dalam penelitian Penyusunan Aplikasi Basis Data Pohon Kota Studi Kasus Jakarta Barat ini dibatasi pada jalur hijau pada jalan Palmerah Utara, Palmerah Barat, dan jalan S. Parman segmen Jembatan Slipi sampai Slipi Jaya.
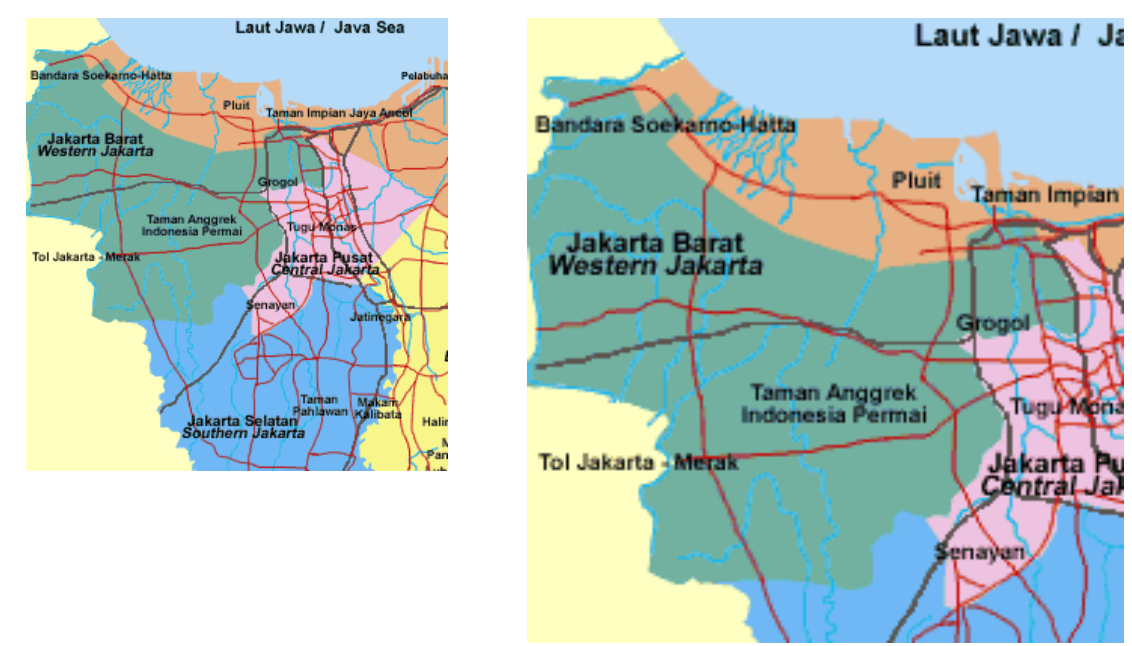

Gambar 1. Peta Lokasi Penelitian

\section{Bahan dan Alat}

\section{Bahan}

Bahan yang akan dikaji lebih lanjut yang akan digunakan dalam penelitian ini adalah sebagai berikut: (1) Data pengelolaan pertamanan dan jalur hijau DKI Jakarta; (2) Data pendukung.

\section{Alat}

Pada kegiatan studi ini alat-alat yang digunakan terdiri atas 2 macam, yaitu: Perangkat lunak (software) dan Perangkat keras (hardware). Perangkat lunak digunakan sebagai alat bantu analisis dalam mengkaji dan mempermudah operasi data-data yang diperoleh di lapang, yang terdiri atas: (1) Php; (2) MySQL; (3) Macromedia Dreamweaver; (4) Google Map API. 
Perangkat keras digunakan untuk menjalankan aplikasi dari perangkat lunak di atas, dengan spesifikasi alat: PC Pentium 4 Dual Core $3.4 \mathrm{GHz}$, DDR1 RAM 1 GB. Seleain itu, untuk membantu didalam inventarisasi data di lapang digunakan alat-alat yaitu: (1) GPS Garmin; (2) Kamera Digital; (3) Roll-meter.

\section{Metode Pengambilan Data}

Metode kegiatan survei pohon jalur hijau yang dilakukan adalah metode survey dan studi pustaka. Metode survey dilakukan dengan mengamati kondisi fisik pohon tepi jalan di beberapa ruas jalan di Jakarta Barat, sedangkan studi pustaka dilakukan untuk memperoleh informasi mengenai standar pemeliharaan pohon. Secara umum penelitian dibagi dalam 3 tahap, yaitu : (1) Pengumpulan data pohon di lapang; (2) Pengolahan basis data pohon; (3) Penyajian akhir.

\section{Pengumpulan Data Pohon di Lapang}

\section{Inventarisasi dan Pengukuran Fisik Pohon}

Inventarisasi dan pengukuran kondisi fisik pohon dilakukan pada 5 aspek yaitu: (1) Diameter batang setinggi dada atau Diameter at Breast Height (DBH); (2) Tinggi pohon; (3) Lebar tajuk; (4) Bentuk tajuk; (5) Lokasi titik tumbuh pohon.

\section{(1) Diameter batang setinggi dada atau Diemeter at the Breast Height (DBH)}

Pengukuran DBH batang pohon dilakukan kurang lebih 140-145 cm dari permukaan tanah dengan menggunakan Rollmeter. Data DBH yang diperoleh kemudian diklasifikasikan kedalam 4 kategori kelas table.

Tabel 1. Kategori kelas DBH Pohon

\begin{tabular}{|l|c|c|}
\hline Kelas & Kualifikasi & Diameter(cm) \\
\hline D1 & Semai & DBH $<10$ \\
\hline D2 & Tiang (kecil) & $10 \leq \mathrm{DBH}<30$ \\
\hline D3 & Hampir dewasa (sedang) & $30 \leq \mathrm{DBH}<60$ \\
\hline D4 & Dewasa (besar) & $\mathrm{DBH}>60$ \\
\hline
\end{tabular}

Sumber: Daniel et. Al. (1995) dalam Dinas Pertamanan Kotamadya Jakarta Timur (2006) 


\section{(2) Tinggi Pohon}

Pengukuran tinggi pohon dengan menggunakan Klinometer untuk memperoleh sudut atas pohon. Tinggi pohon diperoleh melalui perhitungan dengan rumus, sebagai berikut:

$$
T=((\sin \alpha) * L)+\text { tinggi pengamat }
$$

Keterangan :

$\mathrm{T}=$ tinggi pohon (meter)

$\alpha=$ Sudut atas $\left(^{0}\right)$

$\mathrm{L}=$ jarak pengamat dari pohon (meter)

Data tinggi pohonyang diperoleh selanjutnya diklasifikasikan dalam 3 kelas seperti yang terlihat pada tabel.

Tabel 2. Kelas tinggi pohon berdasarkan karakteristiknya

\begin{tabular}{|l|c|c|}
\hline Kelas & Kualifikasi & Lebar (m) \\
\hline T1 & Rendah & $\mathrm{T}<9$ \\
\hline T2 & Sedang & $9 \leq \mathrm{T}<18$ \\
\hline T3 & Tinggi & $\mathrm{T} \leq 18$ \\
\hline
\end{tabular}

Sumber: Daniel et. Al. (1995) dalam Dinas Pertamanan Kotamadya Jakarta Timur (2006)

\section{(3) Lebar Tajuk}

Lebar tajuk diukur menggunakan Rollmeter. Data lebar tajuk yang diperoleh diklasifikasi menjadi 4 kelas.

Tabel 3. Kelas lebar tajuk

\begin{tabular}{|l|c|c|}
\hline Kelas & Kualifikasi & Lebar (m) \\
\hline L1 & Semai & $\mathrm{L}<2$ \\
\hline L2 & Kecil & $2 \leq \mathrm{L}<5$ \\
\hline L3 & Sedang & $5 \leq \mathrm{L}<9$ \\
\hline L4 & Besar & $\mathrm{L} \leq 9$ \\
\hline
\end{tabular}

Sumber: Daniel et. Al. (1995) dalam Dinas Pertamanan Kotamadya Jakarta Timur (2006) 
(4)

\section{Bentuk Tajuk}

Data bentuk tajuk dibagi menjadi 2 kategori, yaitu simetris dan asimetris. Simetris merupakan bentuk tajuk yang sesuai dengan bentuk arsitektur tajuk pohon, sedangkan asimetris adalah bentuk yang tidak sesuai dengan bentuk arsitektur tajuk pohon.

\section{Lokasi Tumbuh Pohon}

Data ini diperoleh dengan menggunakan GPS (Global Positioning System). Dalam bentuk koordinat Latitude Longitude, data tersebut kemudian dipetakan pada peta rupa bumi Google Map.

\section{Penilaian Kondisi Fisik Pohon}

Penilaian kondisi fisik pohon didasarkan pada 3 kerusakan, yaitu kerusakan hama dan penyakit tanaman ,mekanik, dan teknik. Pengamatan kondisi fisik pohon dilakukan berdasarkan kondisi visual pohon dengan penekanan pada bagian pangkal akar yang berada di permukaan tanah, batang, daun, dan percabangan.

Penilaian persentase kerusakan pohon hanya berdasarkan 2 kerusakan, yaitu kerusakan oleh hama/penyakit dan kerusakan mekanik. Untuk kerusakan teknik akan diuraikan secara deskriptif berdasarkan pengamatan visual dilapang. Sistem penilaian kerusakan pohon berdasarkan sistem scoring/nilai sebagai berikut :

\section{Kerusakan oleh Hama dan Penyakit}

Pengamatan kerusakan yang disebabkan hama dan penyakit tanaman menjadi 2 bagian, yaitu:

- Kerusakan hama dan penyakit pada pangkal akar di permukaan tanah dan batang.

- Kerusakan hama dan penyakit tanaman pada cabang dan daun 
Tabel 4. Kerusakan hama dan penyakit tanaman pada pangkal akar dan batang

\begin{tabular}{|l|c|c|}
\hline No. & Kerusakan Hama dan Penyakit & Nilai \\
\hline 1 & Tidak ada kerusakan hama dan penyakit & 0 \\
\hline 2 & Tumbuhan tidak parasit & 1 \\
\hline 3 & Tumbuhan parasit (jamur dan benalu) & 2 \\
\hline 4 & Batang kering/lapuk; Akar kering/lapuk & 3 \\
\hline 5 & Batang busuk; Akar busuk & 4 \\
\hline 6 & Gerowong/keropos yang tampak pada batang utama & 5 \\
\hline
\end{tabular}

Sumber: Dinas Pertamanan Kotamadya Jakarta Timur (2006)

Tabel 5. Kerusakan hama dan penyakit tanaman pada cabang dan daun

\begin{tabular}{|l|c|c|}
\hline No. & Kerusakan Hama dan Penyakit & Nilai \\
\hline 1 & Tidak ada kerusakan hama dan penyakit & 0 \\
\hline 2 & Tumbuhan tidak parasit & 1 \\
\hline 3 & Tumbuhan parasit (jamur dan benalu) & 2 \\
\hline 4 & Klosorsis & 3 \\
\hline 5 & Nekrosis & 4 \\
\hline 6 & Percabangan lapuk & 5 \\
\hline
\end{tabular}

Sumber: Dinas Pertamanan Kotamadya Jakarta Timur (2006)

Untuk menghitung tingkat kerusakan karena hama dan penyakit pada pangkal akar dan batang digunakan rumus:

$$
\mathrm{T}_{\mathrm{ab}}=\left(\mathrm{n}_{\mathrm{i} \times 100}\right) / \sum \mathrm{n}_{\mathrm{i}}
$$

$\mathrm{T}_{\mathrm{ab}} \quad=$ Tingkat kerusakan hama/penyakit pada pangkal akar dan batang

$\mathrm{n}_{\mathrm{i}} \quad=$ Nilai

$\sum \mathrm{n}_{\mathrm{i}}=$ Jumlah total nilai dari kerusakan hama dan penyakit pada pangkal akar dan batang

Sedangkan tingkat kerusakan hama dan penyakit pada cabang dan daun dapat dihitung dengan menggunakan rumus:

$$
\begin{aligned}
& \mathrm{T}_{\mathrm{cd}}=\left(\mathrm{n}_{\mathrm{i} \times 100}\right) / \sum \mathrm{n}_{\mathrm{i}} \\
& \mathrm{T}_{\mathrm{cd}} \quad=\text { Tingkat kerusakan hama/penyakit pada pangkal akar dan batang } \\
& \mathrm{n}_{\mathrm{i}} \quad=\text { Nilai } \\
& \sum \mathrm{n}_{\mathrm{i}}=\text { Jumlah total nilai dari kerusakan hama dan penyakit pada } \\
& \text { pangkal cabang dan daun }
\end{aligned}
$$


Untuk menghitung total tingkat kerusakan hama dan penyakit menggunakan rumus :

$$
\mathrm{T}_{\mathrm{hpt}}=\left(\mathrm{T}_{\mathrm{ab}}+\mathrm{T}_{\mathrm{cd}}\right) / 2
$$

$\mathrm{T}_{\text {hpt }}=$ tingkat kerusakan oleh hama dan penyakit pohon

$\mathrm{T}_{\mathrm{ab}}=$ tingkat kerusakan oleh hama dan penyakit pohon pangkal akar dan batang

$\mathrm{T}_{\mathrm{cd}}=$ tingkat kerusakan oleh hama dan penyakit pohon pangkal cabang dan daun

Tingkat kerusakan hama dan penyakit yang telah diperoleh kemudoan dikategorikan dalam peringkat sebagai berikut (Tabel 6):

Tabel 6. Tingkat kerusakan hama dan penyakit pada pohon

\begin{tabular}{|l|c|c|}
\hline No & Kualifikasi & Serangan(\%) \\
\hline 1 & Tidak ada & $0 \leq \mathrm{T}_{\mathrm{hpt}}<15$ \\
\hline 2 & Sedikit & $15 \leq \mathrm{T}_{\mathrm{hpt}}<30$ \\
\hline 3 & Banyak & $30 \leq \mathrm{T}_{\mathrm{hpt}}<50$ \\
\hline 4 & Sangat banyak & $\mathrm{T}_{\mathrm{hpt}} \geq 50$ \\
\hline
\end{tabular}

Sumber: Dinas Pertamanan Kotamadya Jakarta Timur (2006)

\section{(2) Kerusakan Mekanik}

Kerusakan mekanik merupakan kerusakan pada pohon yang disebabkan oleh kontak dengan benda-benda fisik (gesekan, goresan, benturan, dan sebagainya). Pengamatan yang dilakukan berdasarkan sistem nilai (Tabel 7).

Tabel 7. Tingkat kerusakan mekanik pada pohon

\begin{tabular}{|l|c|c|}
\hline No & Kerusakan Mekanik & Nilai \\
\hline 1 & Tidak ada kerusakan mekanik & 0 \\
\hline 2 & Corat-coret/Reklame & 1 \\
\hline 3 & Goresan & 2 \\
\hline 4 & Sayatan & 3 \\
\hline 5 & Patah cabang & 4 \\
\hline 6 & Tersambar petir & 5 \\
\hline
\end{tabular}

Sumber : Dinas Pertamanan Kotamadya Jakarta Timur (2006) 
Selanjutnya tingkat kerusakan mekanik pada pohon dapat dihitung menggunakan rumus:

$$
\begin{aligned}
& \qquad \mathrm{T}_{\mathrm{M}}=\left(\mathrm{n}_{\mathrm{i} \times 100}\right) / \sum \mathrm{n}_{\mathrm{i}} \\
& \mathrm{T}_{\mathrm{M}}=\text { Tingkat kerusakan mekanik pada pohon } \\
& \mathrm{n}_{\mathrm{i}}=\text { Nilai } \\
& \sum \mathrm{n}_{\mathrm{i}}=\text { Jumlah total nilai dari kerusakan mekanik pada pohon }
\end{aligned}
$$

Tingkat kerusakan mekanik yang diperoleh kemudian dikategorikan dalam peringkat sebagai berikut (Tabel 8):

Tabel 8. Tingkat kerusakan mekanik pada pohon

\begin{tabular}{|l|c|c|}
\hline No & Kualifikasi & Serangan (\%) \\
\hline 1 & Tidak ada & $0 \leq \mathrm{T}_{\mathrm{m}}<15$ \\
\hline 2 & Sedikit & $15 \leq \mathrm{T}_{\mathrm{m}}<30$ \\
\hline 3 & Banyak & $30 \leq \mathrm{T}_{\mathrm{m}}<50$ \\
\hline 4 & Sangat banyak & $\mathrm{T}_{\mathrm{m}} \geq 50$ \\
\hline
\end{tabular}

Sumber: Dinas Pertamanan Kotamadya Jakarta Timur (2006)

Persentase kerusakan hama dan penyakit dan kerusakan mekanik kemudian digunakan untuk memperoleh tingkat kerusakan total pohon dengan menggunakan rumus:

$$
\begin{gathered}
\mathrm{T}=\left(\mathrm{T}_{\mathrm{hpt}}+\mathrm{T}_{\mathrm{m}}\right) / 2 \\
\mathrm{~T}=\text { Total tingkat kerusakan pohon } \\
\mathrm{T}_{\mathrm{hpt}}=\text { Tingkat kerusakan oleh hama dan penyakit pada pohon } \\
\mathrm{T}_{\mathrm{M}}=\text { Tingkat kerusakan mekanik pada pohon }
\end{gathered}
$$

Data tingkat kerusakan pohon yang diperoleh kemudian dikategorikan berdasarkan peringkat sesuai dengan metode Grey dan Deneke (1978) yang telah dimodifikasi:

a. Peringkat 1 (sangat baik)

Pohon sehat dan vigor. Rata-rata serangan hama penyakit dan kerusakan mekanik $0 \% \leq \mathrm{T}<15 \%$. Sedikit atau tidak memerlukan perbaikan. 


\begin{abstract}
b. Peringkat 2 (baik)
Pohon cukup baik. Rata-rata serangan hama penyakit dan kerusakan mekanik $15 \% \leq \mathrm{T}<30 \%$. Memerlukan perbaikan.

c. Peringkat 3 (buruk)

Pohon kurang baik dan kurang sehat. Rata-rata serangan hama penyakit dan kerusakan mekanik 30\% $\leq \mathrm{T}<50 \%$. Memerlukan banyak tindakan perbaikan

d. Peringkat 4 (sangat buruk)

Pohon dengan rata-rata serangan hama penyakit dan kerusakan mekanik $\mathrm{T}_{\mathrm{m}} \geq 50$ atau terancam mati, atau mati.
\end{abstract}

\title{
Pemetaan Data Pohon
}

Data hasil pengukuran lapangan dan data dari GPS (Global Positioning System) dimasukkan ke dalam aplikasi Garmin untuk mendapatkan data posisi pohon dengan format Latitude Longitude. Hasil yang didapat kemudian akan diinput secara manual ke dalam basis data bersama informasi pohon lainnya untuk dipetakan di dalam interface aplikasi yang sudah dikoneksikan dengan Google Map.

\section{Pengolahan Basis Data Pohon}

Pengolahan data spasial dilakukan menggunakan Google Map API yang dapat menghubungkan Google Map dan aplikasi basis data pohon. Sedangkan pengelolaan data atribut berupa angka dan huruf dengan program MySQL. Aplikasi yang digunakan untuk menghubungkan kedua program sehingga mendapatkan tampilan yang interaktif adalah Macromedia Dreamweaver 8 . Bahasa pemrograman yang digunakan adalah Php.

\section{Penyajian Hasil}

Penyajian hasil aplikasi basis data pengelolaan pohon kota ini akan dijalankan dalam web browser yang dapat di-posting pada jaringan internet maupun localhost pada server. 


\section{HASIL DAN PEMBAHASAN}

\section{Hasil}

\section{Pengambilan Data Pohon}

Pengambilan data pohon dilakukan di Jakarta Barat, sampel pohon yang diambil terdapat di jalan Palmerah Barat, Palmerah Utara dan jalan S Parman segmen Jembatan Slipi - Pasar Slipi. Pengambilan data pohon di lapang menggunakan alat bantu untuk mencatat kondisi pohon di lapang berupa form/lembaran yang telah disesuaikan dengan Form Input data pohon pada tampilan basis data. Sedangkan untuk mengetahui koordinat Latitude Longitude pohon menggunakan GPS dan untuk merekam foto/gambar pohon menggunakan kamera dijital.

Pada pengambilan data pohon ini dilakukan pengkodean pada setiap pohon, pengkodean disesuaikan dengan nama jalan, misalnya pada jalan Palmerah digunakan kode "PALM" dan jalan S Parman digunakan kode "SPRM”. Namun pengkodean pohon ini bersifat fleksibel sehingga bisa disesuaikan dengan kebutuhan.

\section{Pengelolaan Data Gambar}

Gambar-gambar eksisting pohon di lapang dimasukkan ke dalam basis data dengan format JPEG (Joint Photographic Experts Group) yang telah disesuaikan dengan program basis data, seperti memperkecil ukuran dari ukuran standar kamera dijital yang bertujuan untuk mrngurangi atau menghemat kapasitas hardisk pada komputer. Gambar-gambar tersebut disimpan pada folder khusus yang telah ditentukan.

\section{Pengelolaan Data Peta}

Data hasil pengukuran lapang yang menggunakan GPS (Global Positioning Sistem) dimasukkan ke dalam sebuah software Garmin untuk mendapatkan data koordinat pohon dengan format Lat Long. Data yang sudah didapatkan kemudian akan dimasukkan ke dalam basis data melalui tampilan form input data pada aplikasi basis data. 


\section{Pembuatan Program Aplikasi}

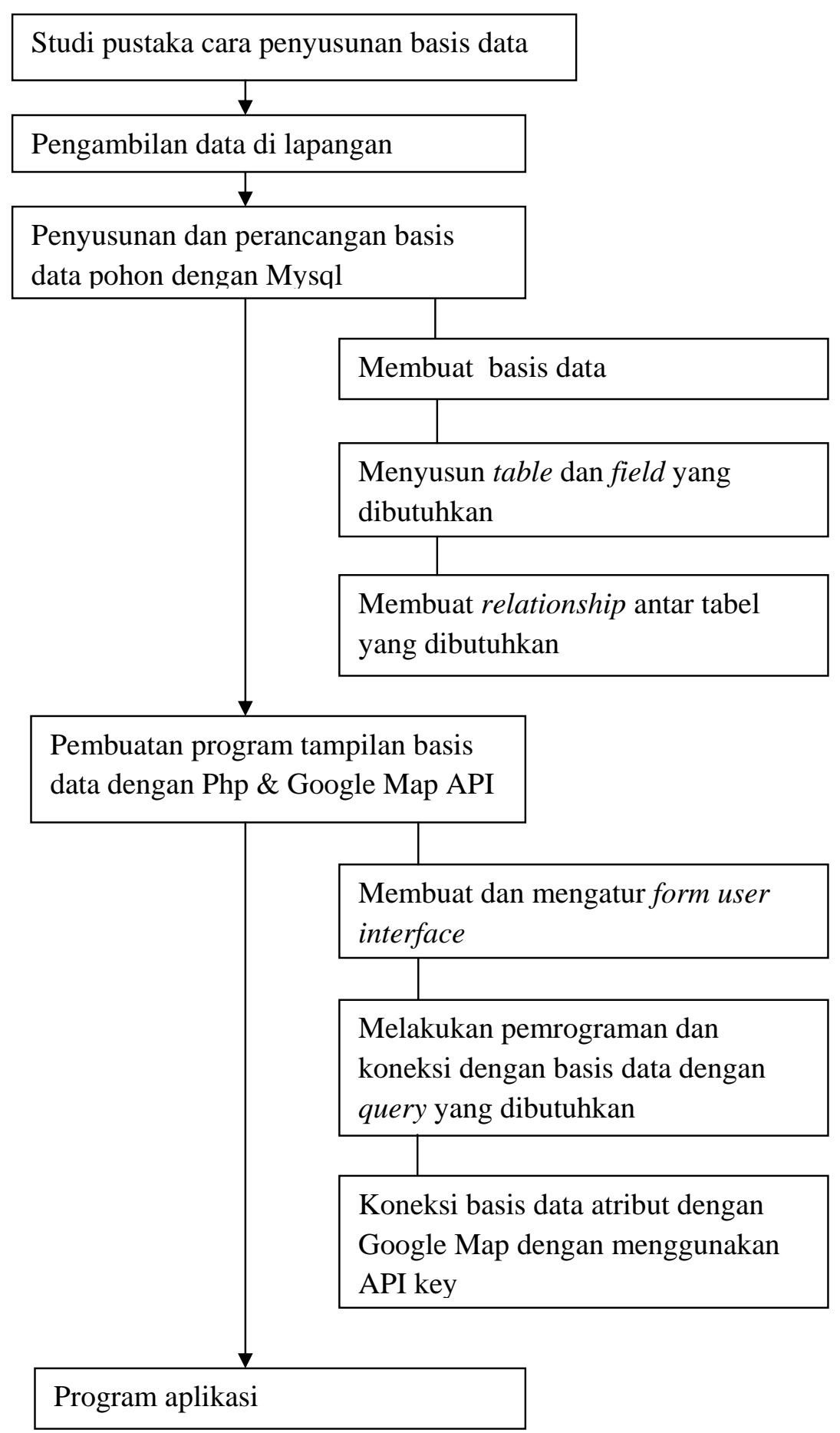

Gambar 2. Skema Pembuatan Aplikasi 
Pembuatan program aplikasi menggunakan software MySQL, Xampp 1.6, PHP, Macromedia Dreamweaver 8, dan Google Map. Penyusunann dan perancangan basis data pohon menggunakan MySQL dengan Xampp 1.6 sebagai alat bantu GUI. Sedangkan pembuatan program tampilan basis data digunakan PHP dengan Macromedia Dreamweaver sebagai alat bantu GUI. Skema pembuatan program aplikasi dapat dilihat pada Gambar 5. Berikut adalah penjelasan mengenai pembuatan program aplikasi:

\section{Penyusunan dan Perancangan Basis Data Pohon dalam MySQL}

Penyusunan basis data pohon sepanjang jalan kolektor ini dirancang untuk menginventarisasi pohon dan memberikan informasi deskripsi, kesehatan, jumlah, dan lokasi pohon di sepanjang jalan. Penyusunan basis data pohon ini dapat memberikan kemudahan bagi pengguna dalam mendapatkan informasi secara cepat dan menginventarisasi pohon di lapangan. Data tabel yang dibuat pada sistem ini disusun berdasarkan standar inventarisasi yang digunakan oleh dinas pertamanan. Penyusunan standar pendataan dari berbagai institusi lain juga telah menjadi pertimbangan tetapi standar dinas pertamanan diambil karena stake holder yang terkait langsung dalam pengelolaan pohon kota ada dinas pertamanan sehingga sistem ini akan lebih mudah digunakan apabila menggunakan standar yang sudah ada.

Penggunaan MySQL didasarkan pada keunggulan aplikasi tersebut dalam menyimpan data yang sangat banyak. Hal ini sangat dibutuhkan apabila penggunaan sistem ini diperluas untuk mendata pohon-pohon pada kota-kota di seluruh Indonesia.

a. Membuat Basis Data dalam MySQL

Dalam pembuatan basis data digunakan Xampp 1.6 sebagai alat bantu untuk menjalankan MySQL. MySQL dijalankan dengan mengetik localhost pada browser setelah MySQL diaktifkan. Setelah itu klik menu phpMyadmin. 


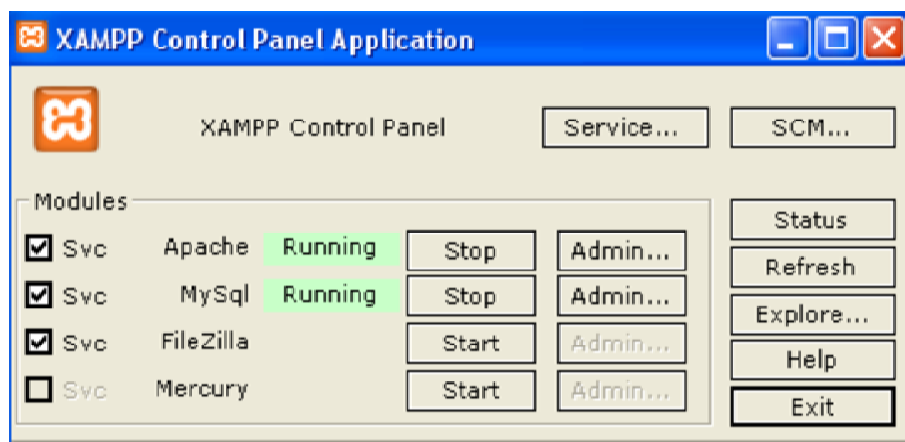

XuMp Control Panel Version 2.5 (9. May, 2007)

windows 5.1 Build 2600 platform 2 Service pack 2

Current Directory: c: \xampp

Install Directory: c: $\backslash x a m p p$

Status Check oR

$<$

$>$

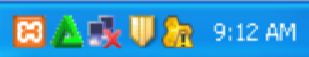

Gambar 3. Mengaktifkan MySQL Melalui Xampp 1.6

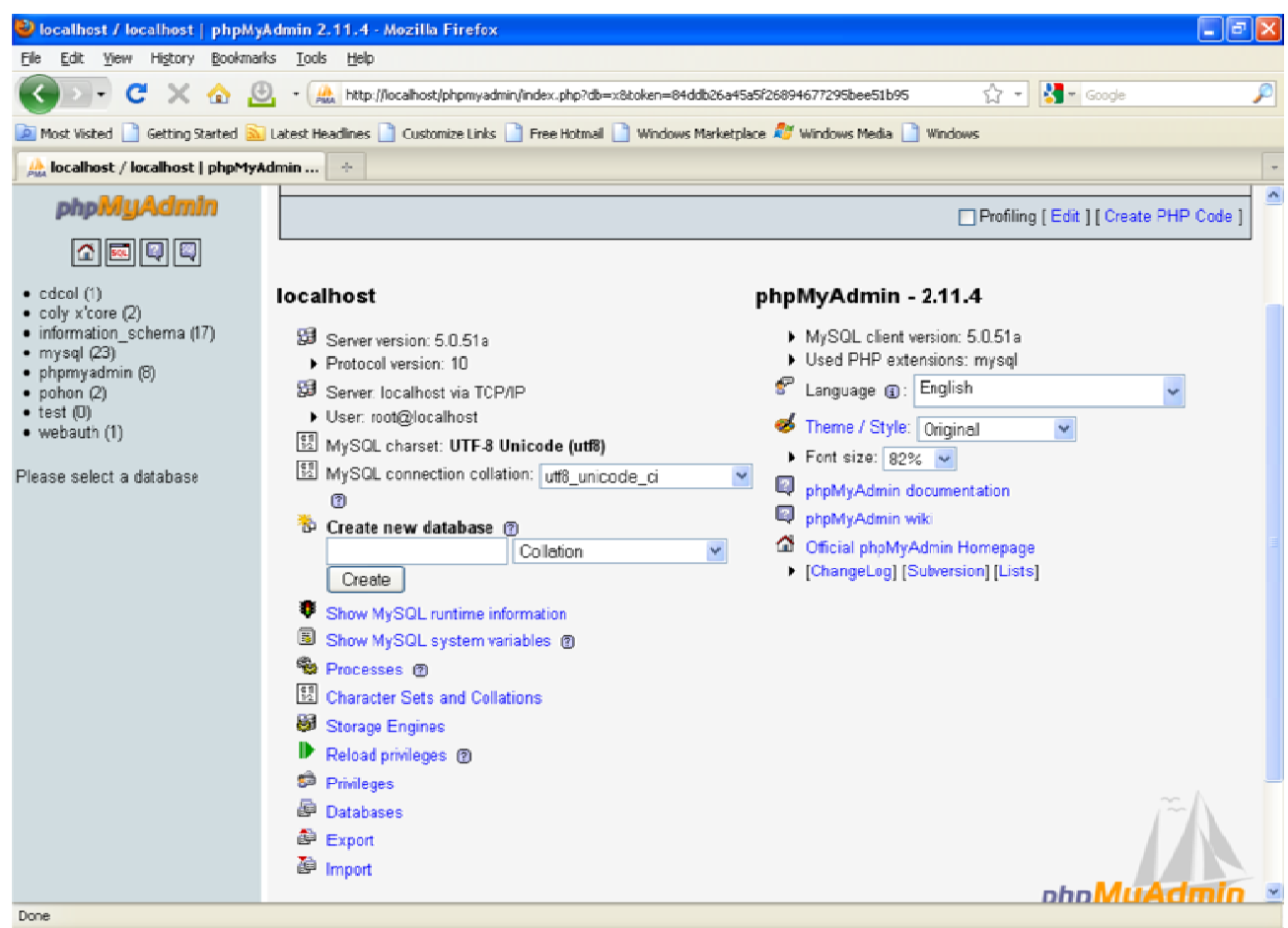

Gambar 4. Tampilan Home MySQL 
Setelah membuka MySQL, kemudian basis data dibuat dengan mengetikkan nama basis data yag akan dibuat pada form Create New Database kemudian klik Create.

b. Merancang dan Membuat Tabel Struktur Basis Data Pohon dalam MySQL

Pembuatan struktur basis data merupakan tahap paling awal dalam penyusunana basis data pohon. Pada tahap ini dilakukan proses seleksi data sehingga dapat memudahkan pemasukkan data dengan tepat sesuai dengan jenis datanya. Struktur basis data akan menetukan tipe data yang akan dimasukkan, jumlah tabel (table) dan kolom (field) yang akan dibuat di dalam basis data serta hubungan (relationship) antar tabel-tabel tersebut. Tabel dan kolom dibuat berdasarkan pengklasifikasian yang telah dilakukan.

1. Tabel data_atribut_pohon, tabel ini terdiri dari $20 \mathrm{kolom} /$ field. Kolom tersebut adalah Id (Primary Key), nama_latin, nama_lokal, nama_jalan, kota, kerusakan_hpta, kerusalan_hptb, kerusakan_mekanik, kerusakan_total, peringkat_kesehatan, diameter_batang, lebar_tajuk, tinggi_pohon, kelas_diameter, kelas_tajuk, kelas_tinggi, bentuk_tajuk, latitude, longitude.

2. Tabel pass pohon terdiri dari dua field. Yaitu nama (Primary Key) dan pass.

Setelah menentukan nama tabel dan jumlah field yang akan dibuat, kemudian klik Go untuk membuat field yang telah ditentukan.

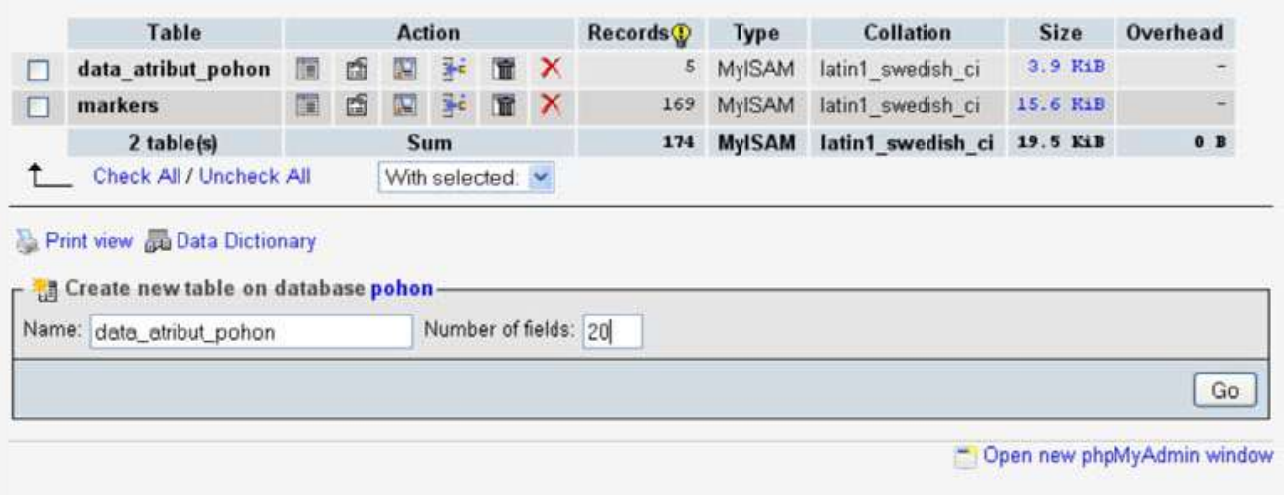

Gambar 5. Tampilan Menu Create Table 
Pada menu pembuatan field juga terdapat fungsi-fungsi untuk mengatur primary key, format, jumlah karakter, dan sebagainya.

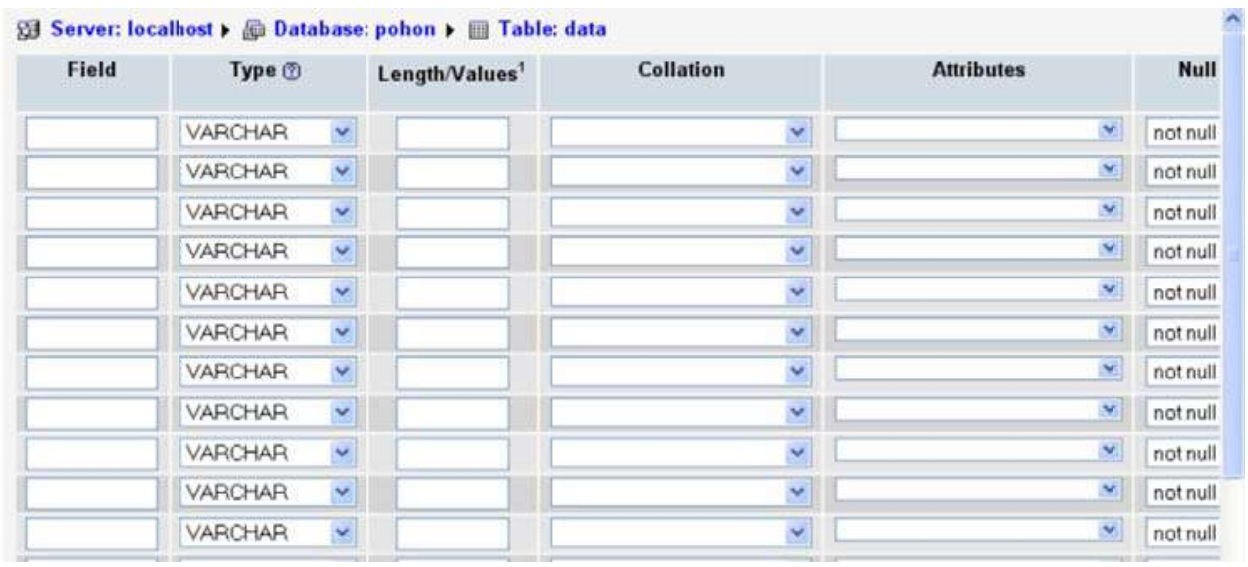

Gambar 6. Tampilan Menu Create Field

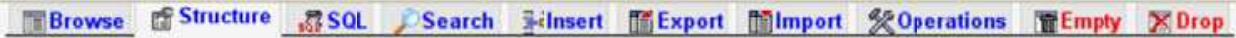

\begin{tabular}{|c|c|c|c|c|c|c|c|c|c|c|c|c|c|c|}
\hline & Field & Type & Collation & Attributes & Null & Default & Extra & \multicolumn{7}{|c|}{ Action } \\
\hline$\square$ & id & varchar(100) & latin1_swedish_ci & & No & & & 同 & $\vartheta$ & $x$ & 8 & U & $\theta$ & $T$ \\
\hline$\square$ & nama_latin & varchar(1000) & latin1_swedish_ci & & No & & & 网 & $\theta$ & $x$ & 87 & 范 & 8 & $T$ \\
\hline$\square$ & nama_lokal & varchar $(100)$ & latin1_swedish_ci & & No & & & 圄 & 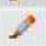 & $x$ & 8 & 河 & 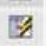 & $T$ \\
\hline$\square$ & latitude & float $(10,6)$ & & & No & & & 成 & $\theta$ & $x$ & 18 & 菏 & 8 & $T$ \\
\hline$\square$ & longitude & float $(10,6)$ & & & No & & & 皬 & $\theta$ & $x$ & ili & E & 8 & $T$ \\
\hline$\square$ & foto & varchar(100) & latin1_swedish_ci & & No & & & 罪 & $\theta$ & $x$ & 89 & T) & 7 & $T$ \\
\hline$\square$ & tinggi & varchar(10) & latin1_swedish_ci & & No & & & 圆 & $\theta$ & $x$ & Ril & Tี & 8 & $T$ \\
\hline$\square$ & lebar_tjk & varchar(10) & latin1_swedish_ci & & No & & & 闰 & $p$ & $x$ & P & 唯 & 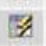 & $T$ \\
\hline$\square$ & diameter & varchar(10) & latin1_swedish_ci & & No & & & 闻 & 8 & $x$ & 18 & एบ & E & $T$ \\
\hline$\square$ & nama jiln & varchar $(80)$ & latin1_swedish_ci & & No & & & 盟 & 8 & $x$ & 18 & II & 略 & $T$ \\
\hline$\square$ & bntk_tjk & varchar(20) & latin1_swedish_ci & & No & & & 묘 & $\gamma$ & $x$ & 18 & Tี & $\Rightarrow$ & $T$ \\
\hline$\square$ & hpta & varchar(10) & latin1_swedish_ci & & No & & & [1] & $\theta$ & $x$ & in & U & 8 & $T$ \\
\hline$\square$ & hptb & varchar(10) & latin1_swedish_ci & & No & & & 闻 & $\theta$ & $x$ & 8 & บ & $B$ & $T$ \\
\hline$\square$ & hpt & varchar(30) & latin1_swedish_ci & & No & & & (7) & $\theta$ & $x$ & 89 & (บ) & $\Rightarrow$ & $T$ \\
\hline$\square$ & mknk & varchar(10) & latin1_swedish_ci & & No & & & 管 & 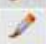 & $x$ & 8 & (บ) & 8 & $T$ \\
\hline$\square$ & total & varchar(30) & latin1_swedish_ci & & No & & & 临 & $\vartheta$ & $x$ & 18 & एบ & 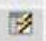 & $T$ \\
\hline$\square$ & prngkt & varchar(15) & latin1_swedish_ci & & No & & & 葍 & 8 & $x$ & 18 & (5) & 8 & $T$ \\
\hline$\square$ & dbh & varchar(20) & latin1_swedish_ci & & No & & & 間 & $\Rightarrow$ & $x$ & 8 & u & 8 & $T$ \\
\hline$\square$ & $\mathbf{L}$ & varchar(20) & latin1_swedish_ci & & No & & & 圆 & 8 & $x$ & R & บ & 8 & $T$ \\
\hline$\square$ & $\mathbf{T}$ & varchar(20) & latin1_swedish_ci & & No & & & (1) & 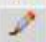 & $x$ & 8 & U & $B$ & $T$ \\
\hline$\square$ & link & varchar $(400)$ & latin1_swedish_ci & & No & & & 国 & 9 & $x$ & 87 & tu & 8 & $T$ \\
\hline$\square$ & kota & varchar(20) & latin1_swedish_ci & & No & & & 目 & 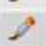 & $x$ & 8 & (บ) & $B$ & $T$ \\
\hline
\end{tabular}

Gambar 7. Tampilan Hasil Field pada Tabel Data_atribut_pohon

\begin{tabular}{|c|c|c|c|c|c|c|c|c|c|c|c|c|c|c|}
\hline & Field & Type & Collation & Attributes & Null & Default & Extra & \multicolumn{7}{|c|}{ Action } \\
\hline$\square$ & user_id & varchar(50) & latin1_swedish_ci & & No & & & 国 & 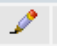 & $x$ & 闐 & 圆 & 䁬 & 䢻 \\
\hline$\square$ & pswrd & varchar(50) & latin1_swedish_ci & & No & & & 罪 & 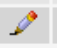 & $x$ & 閴 & 闹 & 係 & 捆 \\
\hline
\end{tabular}

Gambar 8. Tampilan Hasil Field pada Tabel Password 


\section{Pembuatan Program Tampilan Basis Data Menggunakan Php, Macromedia Dreamweaver 8, dan Google Map}

Pembuatan program tampilan basis data ini dikerjakan menggunakan bahasa pemrograman Php dengan Macromedia Dreamweaver 8 sebagai alat bantu GUI. Php adalah pemrograman yang memiliki lisensi open source yang cukup populer untuk membuat aplikasi berbasis web. Untuk menjalankan aplikasi ini dibutuhkan web browser dan juga koneksi internet.

Pengembangan aplikasi basis data dengan Php dilakukan dengan langkahlangkah sebagai berikut:

a. Membuat dan mengatur properti form user interface/tampilan.

Pada basis data pohon ini dibuat 5 form, yaitu:

1. Form Login

Form Login muncul apabila menu login diklik. Form ini dibuat sebagai pengaman, sehingga fitur-fitur tertentu yaitu menu edit data dan input data hanya bisa digunakan apabila pengguna telah melalui halaman login. Pada Form Login objek-objek kontrol yang digunakan yaitu Textfield, Button, Form, dan Recordset.

\section{Form Home}

Form Home berisi tampilan data pohon dalam format tabel. Pada form ini terdapat fungsi search untuk mencari data yang diinginkan dengan mengetikkan kata kunci kemudian klik search. Metode query yang digunakan untuk melakukan pencarian adalah dengan metode Add Fulltext. Objek-objek kontrol yang digunakan antara lain Textfield, Button, Tabel, dan Form. 


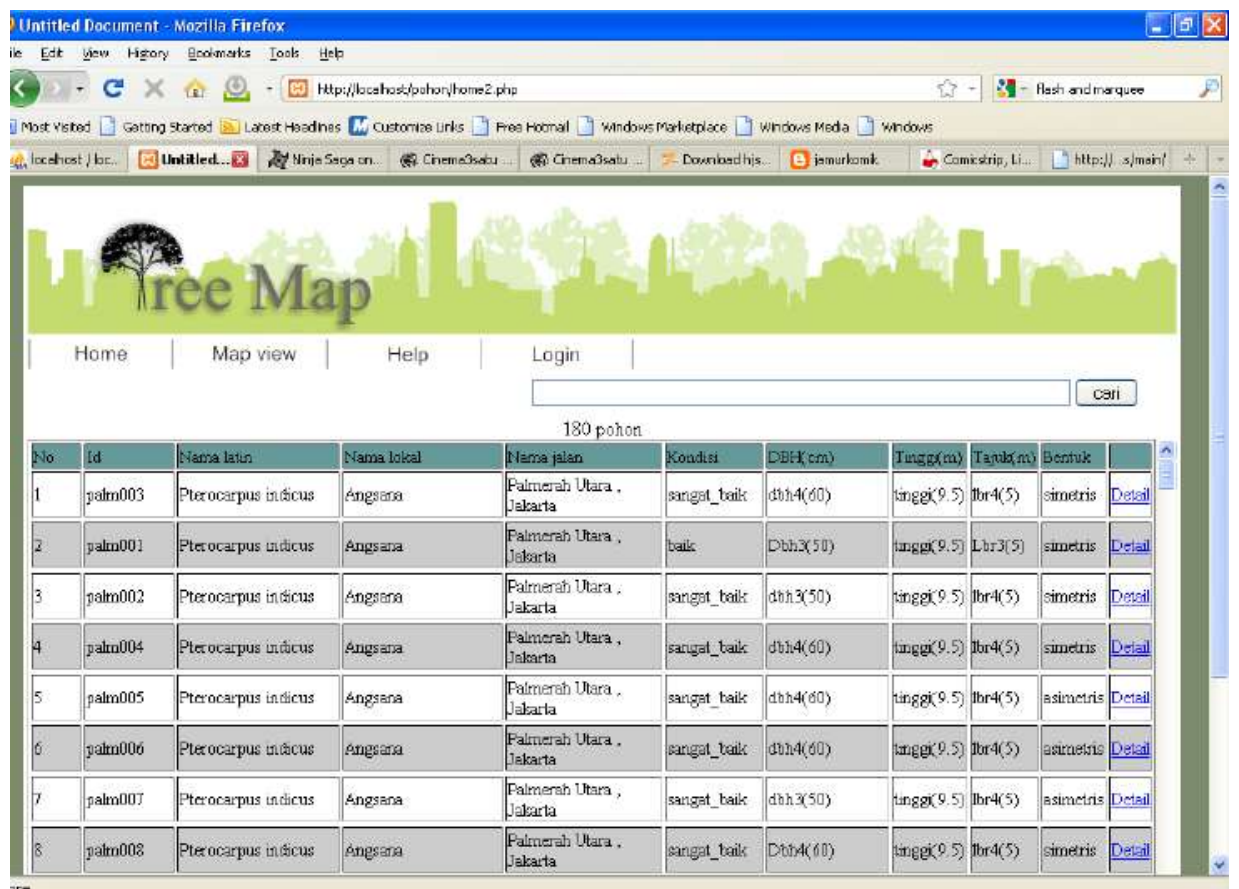

Gambar 9. Tampilan Halaman Home Sebelum Login

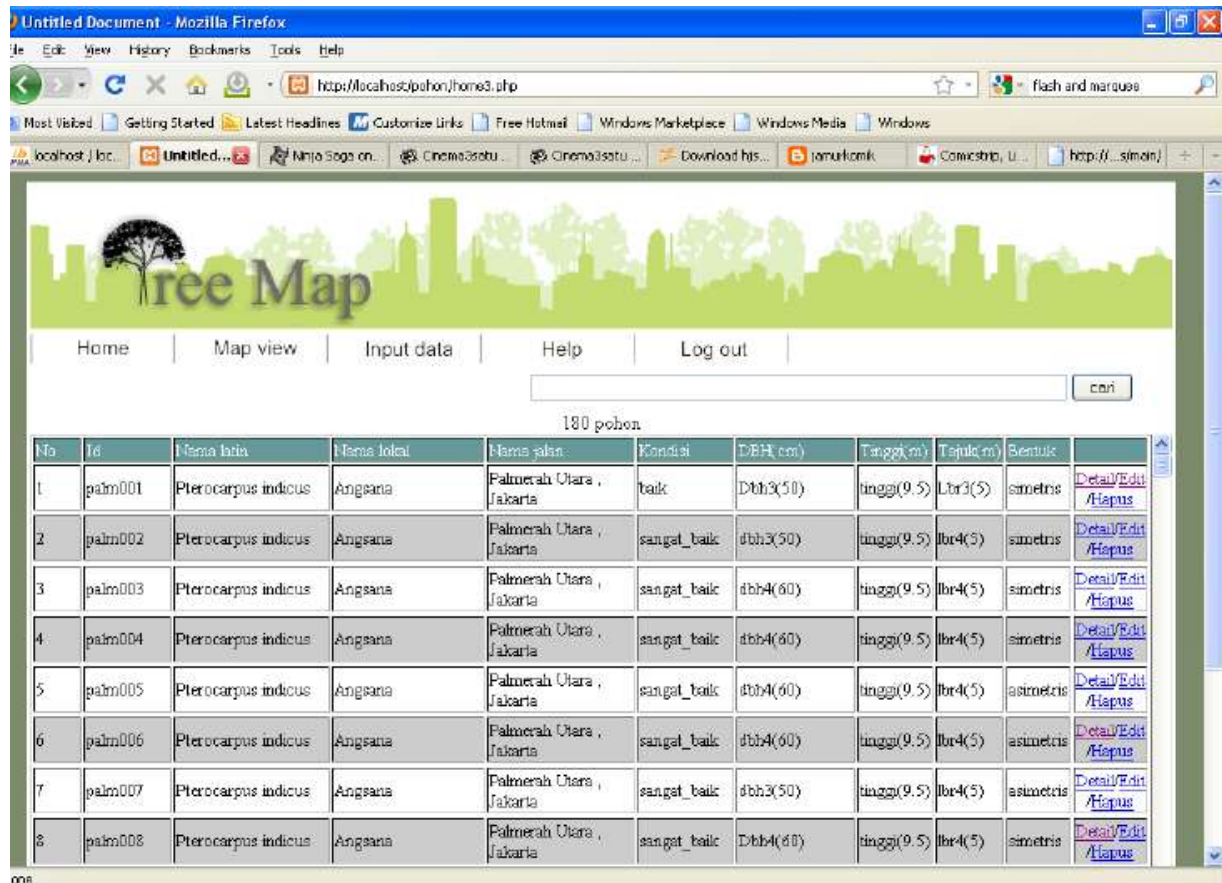

Gambar 10. Tampilan Halaman Home Setelah Login 


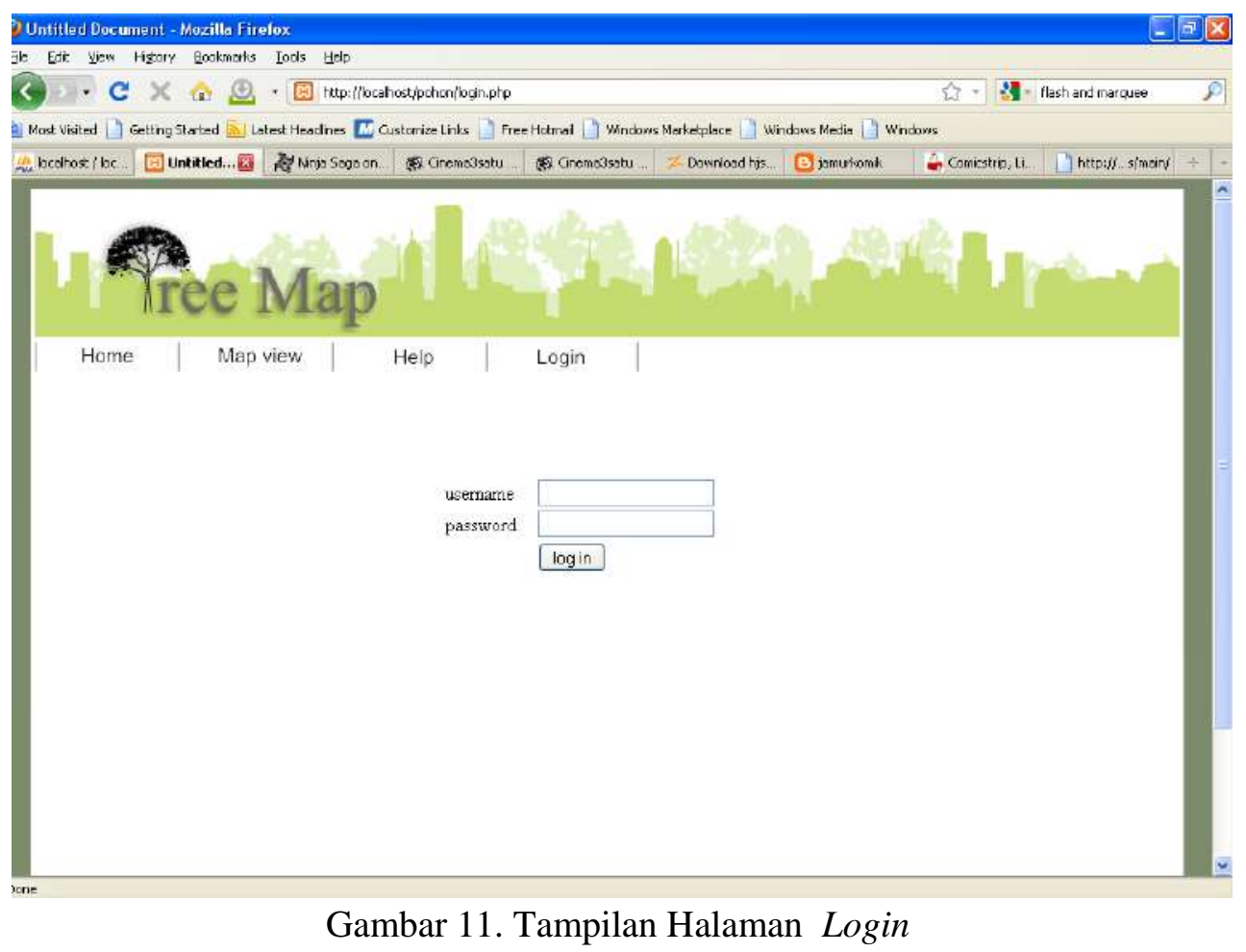

3. Form Input Data

Form input data akan muncul setelah menu Input data di-klik. Menu ini berisi fasilitas unttuk memasukkan data pohon besrupa formulir pendataan pohon yang telah disesuai dengan metode pengumpulan data pohon yang digunakan. Objek kontrol yang digunakan pada form ini adalah Textfield, Button, Checkbox, dan Form. 


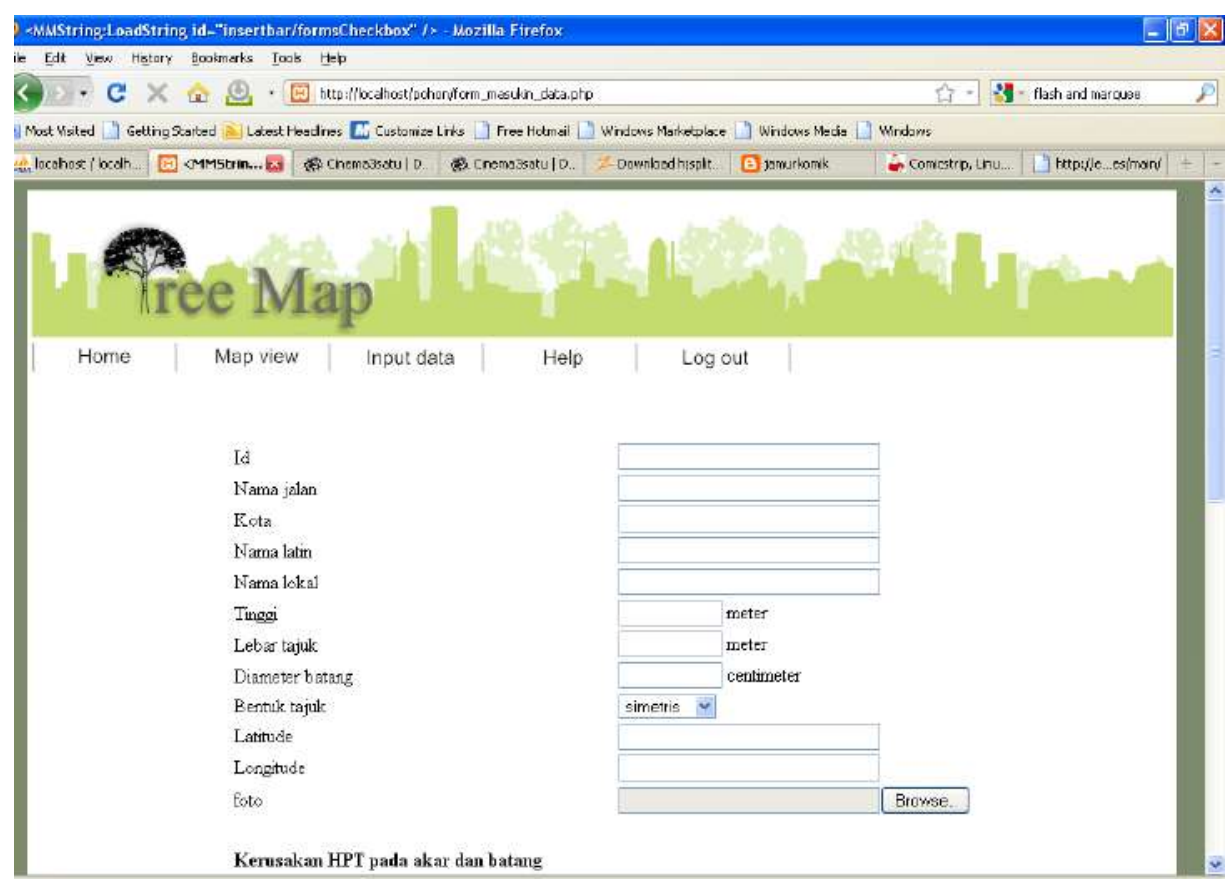

Gambar 12. Tampilan Halaman Input Data

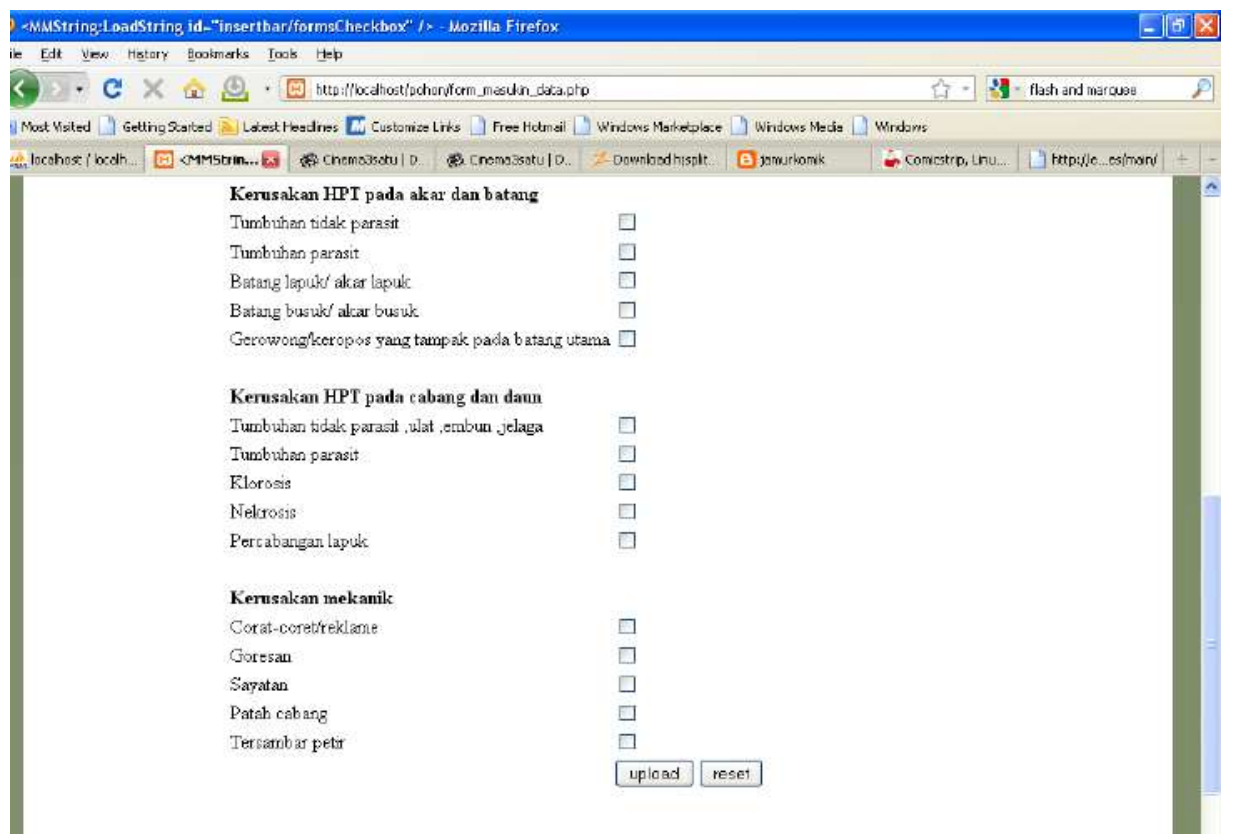

Gambar 13. Tampilan Halaman Input Data Lanjutan

\section{Form Detail}

Form detail berisi data detail pohon yang akan muncul apabila menu detail di-klik. Form ini akan menampilkan data dari tiap pohon sesuai dengan Id yang dimiliki. Pada form ini objek kontrol yang digunakan 
adalah Tabel dan Image. Pada Form Detail, pengguna yang membuka halaman ini tanpa login terlebih dahulu tidak dapat menggunakan menu edit data.

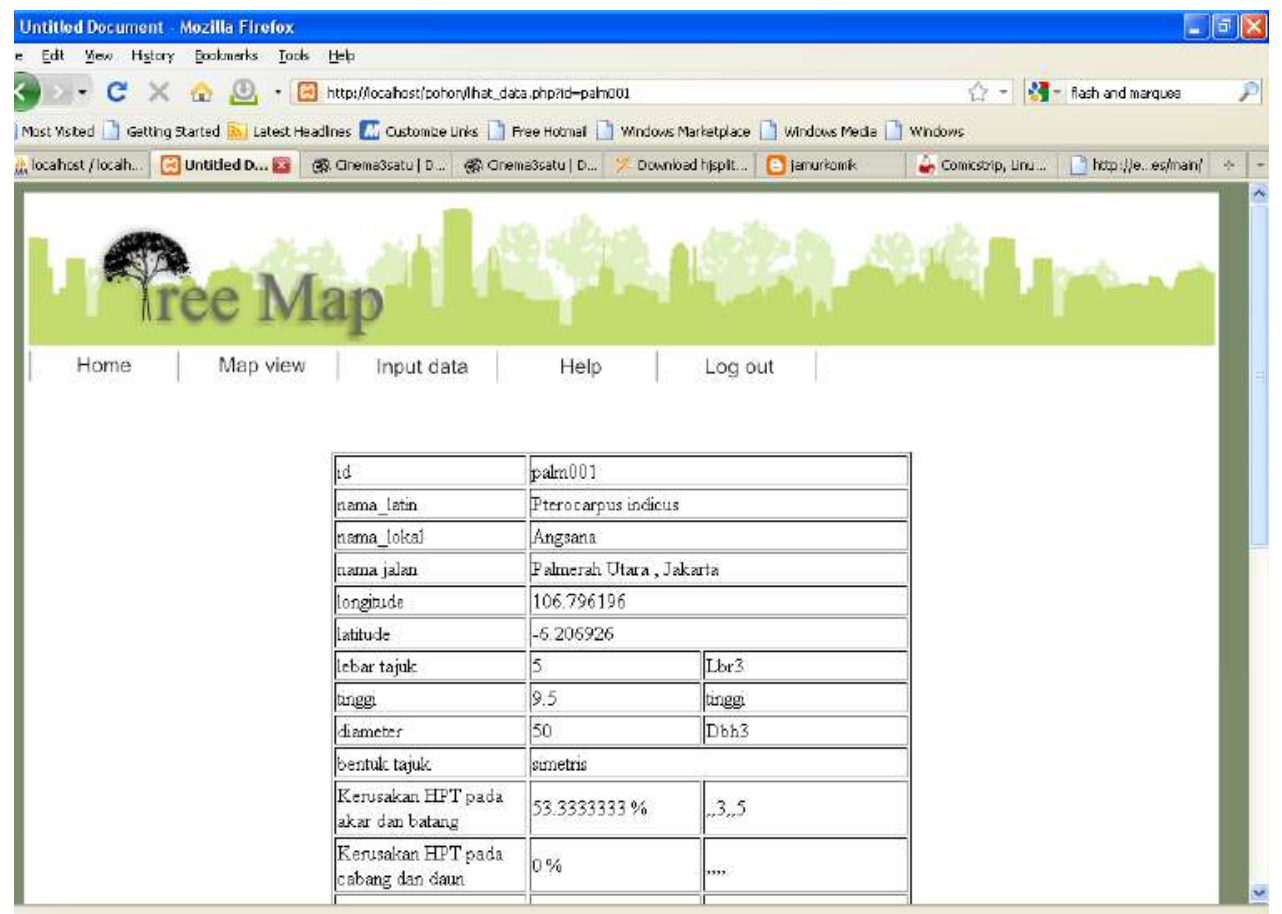

Gambar 14. Tampilan Halaman Detail

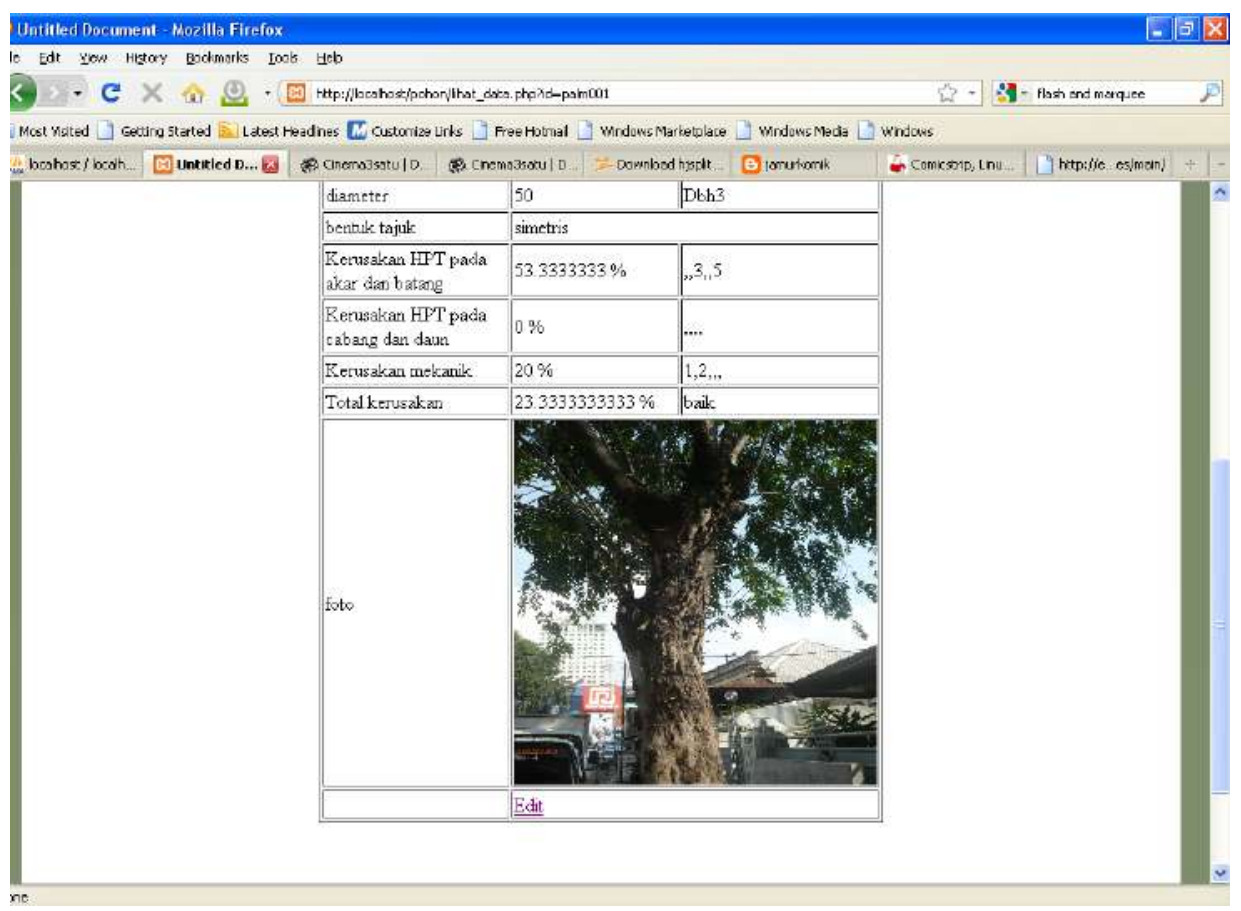

Gambar 15. Tampilan Halaman Detail lanjutan Setelah login 


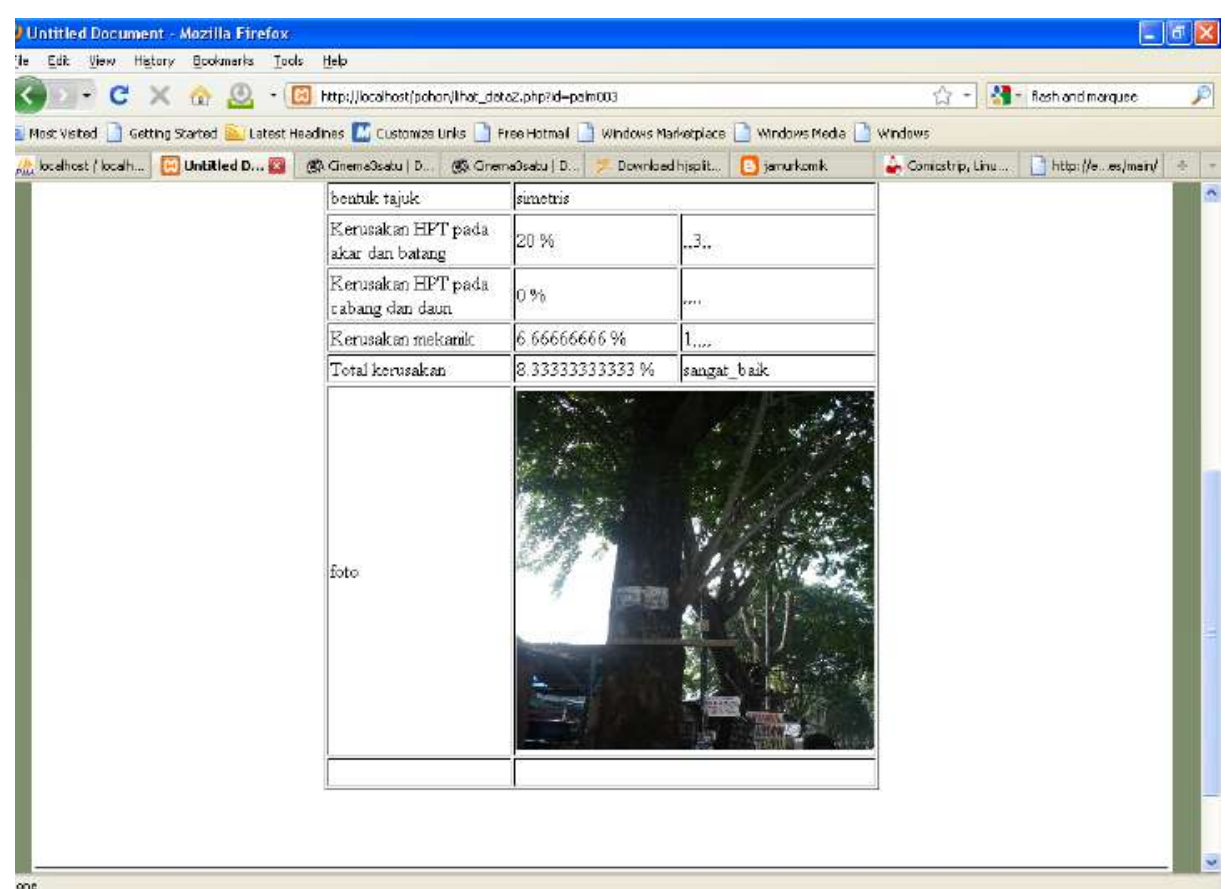

Gambar 16. Tampilan Halaman Detail Lanjutan Tanpa login

\section{Form Map View}

Form map view adalah form yang berfungsi menampilkan peta lokasi pohon sesuai dengan koordinat yang telah dimasukkan ke dalam basis data. Untuk menampilkan peta pohon secara spasial, basis data pohon ini dikoneksikan dengan aplikasi Google Map menggunakan Google Map API Key. Pada Form Map view terdapat fungsi pencarian lokasi berdasarkan Id pohon. Objek kontrol yang terdapat pada menu ini adalah Div, Tabel, Textfield, Button, dan List/Menu. 


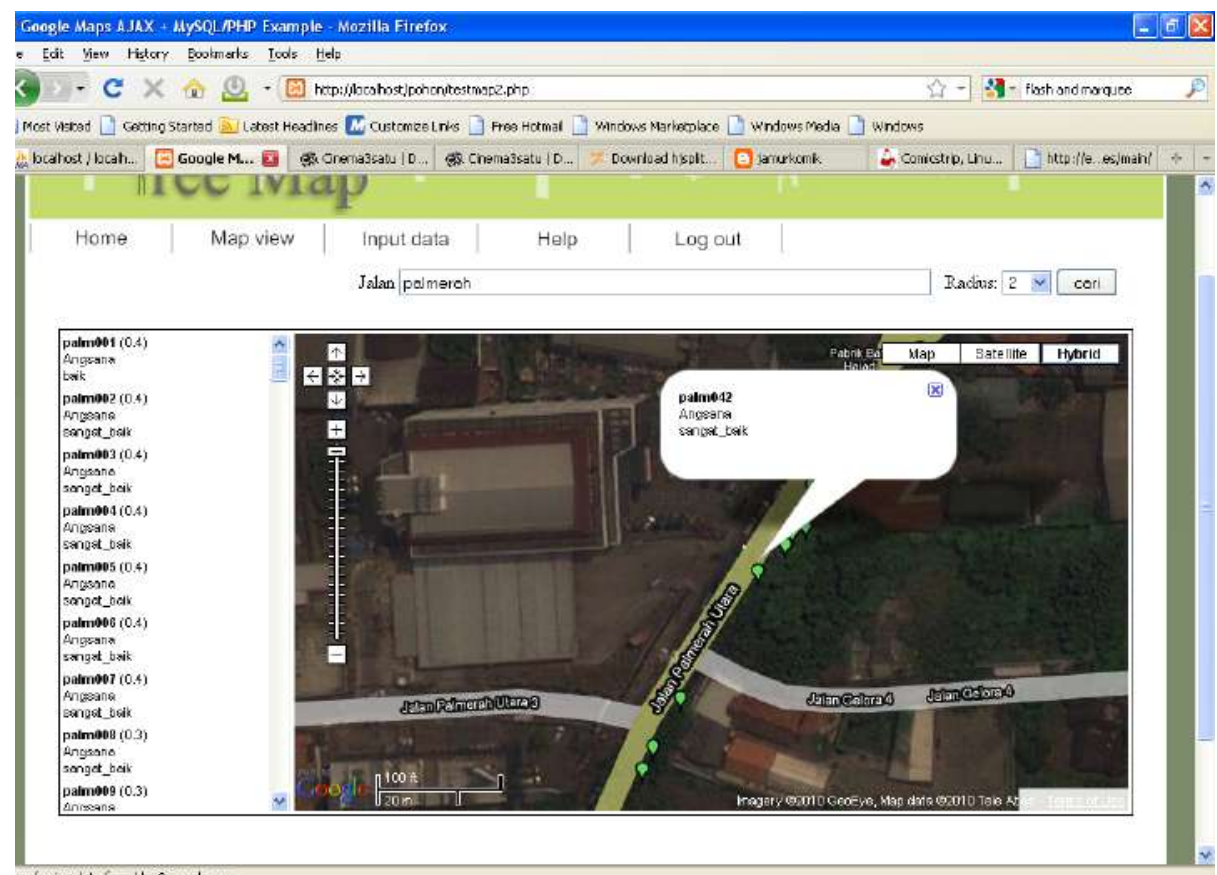

Gambar 17. Tampilan Halaman Map View Dengan Mode Hybrid

\section{Form Help}

Form Help berisi petunjuk penggunaan aplikasi ini dan keterangan mengenai peringkat dan kelas pohon. Objek kontrol yang terdapat pada menu ini adalah Hyperlink dan Named Anchor.

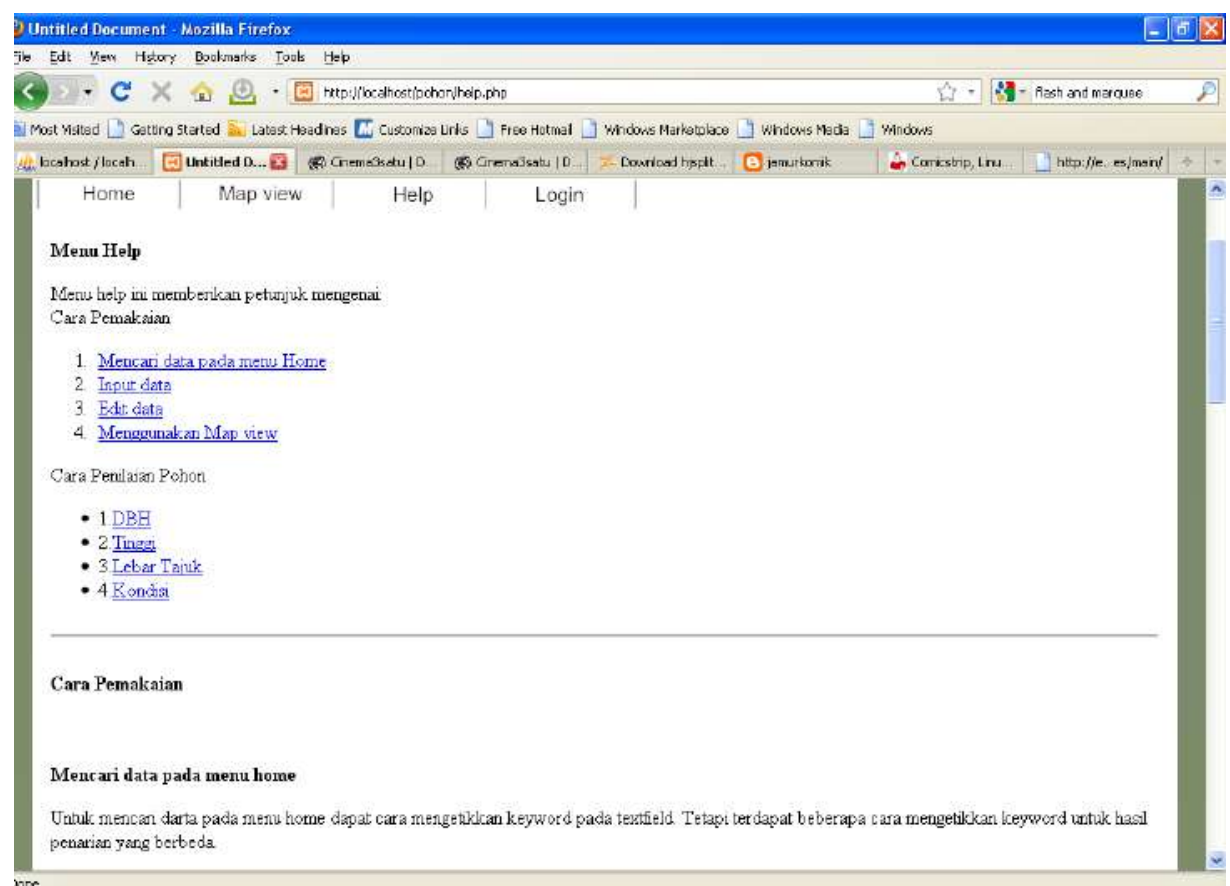

Gambar 18. Tampilan Halaman Help 


\section{b. Menulis Kode Program`}

Penulisan kode program dilakukan setelah pembuatan form dan pengaturan properti selesai. Penulisan kode program ini dilakukan agar tampilan yang telah dibuat dapat dijalankan oleh pengguna/user. Keberhasilan pembuatan aplikasi ditentukan pada penulisan kode program, pada proses ini juga menentukan mudah atau susah suatu aplikasi untuk digunakan. Kode program ditulis pada masingmasing form tersebut. Penulisan dilakukan dengan menggunakan Macromedia Dreamweaver sebagai alat bantu menulis program. Bahasa pemrograman yang digunakan adalah Php.

Untuk menjalankan aplikasi ini melalui localhost dapat dengan membuka porgram menggunakan macromedia dreamweaver dan menekan F12, dengan terlebih dahulu menjalankan $S Q L$ server melalui Xampp. Pada penggunaan aplikasi lebih lanjut, aplikasi ini dapat di-posting di internet dan dijalankan secara online. Kode program pada tiap form dapat dilihat pada lampiran.

\section{Pemasukkan Data Pohon}

Pemasukkan data pohon yang berupa teks atau atribut termasuk pemasukkan data koordinat dan foto dilakukan melalui tampilan aplikasi yang telah selesai dibuat. Data atribut dapat dimasukkan pada halaman input data begitu juga dengan data pohon dan data spasial. Untuk memasukkan data spasial pengguna dapat dimasukkan menggunakan format Latitude Longitude.

\section{Penggunaan Aplikasi Basis Data Pohon}

Aplikasi ini dapat digunakan oleh siapa saja yang membutuhkan, baik institusi atau masyarakat umum. Tetapi aplikasi inventarisasi pohon ini lebih dikhususkan bagi institusi yang mengurusi masalah pohon kota, seperti Dinas Pertamanan maupun pengelola perumahan yang menggunakan standar penilaian yang sama dengan Dinas Pertamanan.

Pada aplikasi ini apabila dijalankan maka yang pertama kali muncul adalah Form home dimana pangguna mendapat pilihan untuk masuk ke dalam Form Map View, Form Detail, dan Form Help, tidak dapat menggunakan fasilitas Input Data dan Edit Data. Untuk dapat menggunakan fasilitas input dan edit data, 
pangguna harus login terlebih dahulu melalui Form Login. Setelah melalui proses login maka Menu Input Data, Edit Data, dan Hapus Data akan muncul. Dari halaman Home, pengguna dapat menuju ke Form Map View, Form Edit, Form Detail, Form Help, Form Input Data dan menjalankan fungsi Hapus Data. Pada Form Home pengguna dapat melihat data pohon kota dalam format tabel dan juga melakukan pencarian data dengan menggunakan kata kunci. Pada halaman ini pengguna dapat melihat tampilan data berupa tabel yang berisi informasi pohon. Informasi yang ditampilkan pada tabel adalah data kualitatif, sehingga apabila pengguna ingin mengetahui perhitungan dan nilai pohon secara detail, pengguna dapat melihat melalui Form Detail pohon.

Pada Form Home juga terdapat fasilitas pencarian dengan penelusuran kata kunci. Metode ini dapat digunakan pengguna untuk mencari informasi spesifik yang diinginkan dengan cepat. Fasilitas ini sangat berguna dalam kasus tertentu salah satunya ketika pada tahun 2009 ditemukan bahwa terdapat beberapa jenis pohon kota di Jakarta beracun, fasilitas pencarian ini dapat membantu menemukan informasi jumlah pohon dan juga lokasi pohon dengan jenis yang dimaksud. Pengelola dapat mengetikkan kata kunci jenis pohon maka pengelola akan langsung mendapatkan informasi yang dibutuhkan untuk menyusun anggaran dan logistik untuk melakukan penangan terhadap kasus tersebut.

Pada Form Input data pengguna dapat memasukkan data-data hasil inventarisasi pohon antara lain: nama lokal, nama latin, nama jalan, nama kota, id pohon, DBH, lebar tajuk, tinggi pohon, kerusakan HPT, kerusakan mekanik, bentuk tajuk, foto, latitude, dan longitude. Pada kategori kerusakan HPT dan kerusakan mekanik tingkat kerusakan pohon dapat langsung dihitung. Untuk masuk kedalam Form Input Data pengguna dapat menekan Menu Input Data. Setelah masuk ke dalam Form Input Data, pengguna dapat mengisi formulir Input Data dan menekan tombol Upload. Pada halaman ini pengguna dapat memasukkan data-data atribut pohon dengan mengetikkan informasi atribut pohon sesuai dengan kriteria. Untuk memasukkan data lokasi pohon pengguna dapat memasukkan data koordinat dengan format Latitude Longitude.

Pada Form Edit Data, pengguna dapat mengubah data yang ada dengan mengisi formulir yang telah ada dan menekan tombol Upload, kemudian data 
yang baru akan merubah data yang lama. Form ini akan muncul setelah pengguna menekan link Edit pada Form Home maupun pada Form Detail.

Form Detail adalah form untuk melihat data pohon secara detail. Untuk masuk ke form ini pengguna dapat mengklik link Detail yang ada pada halaman Home. Pada form ini pengguna dapat melihat data kuantitatif kondisi pohon dan data atribut secara detail, selain itu pengguna juga dapat melihat foto dari pohon yang telah diinventarisasi.

Form Help adalah form yang berisi cara penggunaan aplikasi dan juga tata cara penilaian pohon. Pengguna juga dapat mengetahui rumus perhitungan dan standarisasi yang dilakukan oleh Dinas Pertaman untuk mendapatkan nilai kualitatif kondisi kesehatan pohon.

Form Map View merupakan form yang disediakan untuk melihat peta, lokasi pohon, dan kondisi pohon. Pada Form Map View terdapat tiga tampilan mode peta yaitu Mode Map, Mode Aerial, dan Mode Hybrid. Pada Mode Map, user dapat melihat tampilan berupa peta kota. Pada tampilan aerial pengguna dapat melihat tampilan foto udara dari lokasi. Sedangkan pada Mode Hybrid merupkan overlay dari Mode Map dan Aerial. Untuk pencarian lokasi pohon pada peta pengguna dapat mengetikkan nama jalan pada textfield kemudian klik tombol cari, setelah itu akan muncul daftar pohon pada sidebar peta, setelah itu pengguna dapat mengklik daftar pohon pada sidebar atau simbol pohon untuk melihat kondisi pohon.

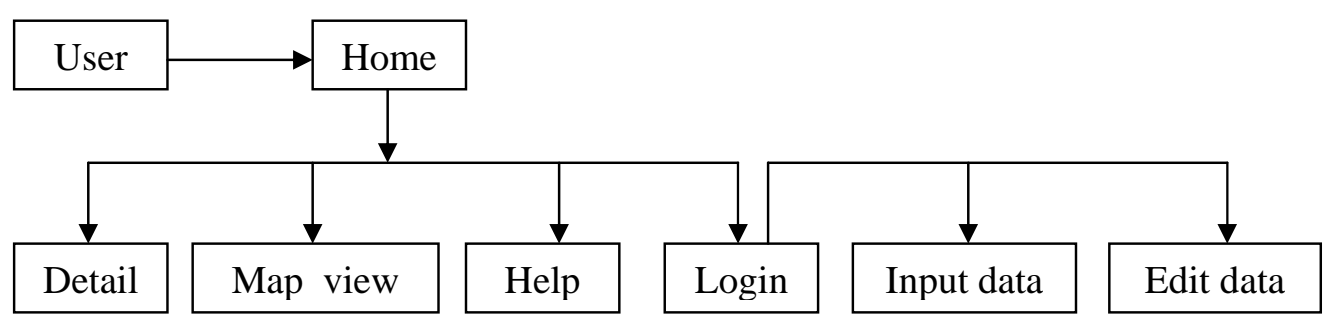

Gambar 19. Skema Penggunaan Aplikasi

Prosedur Penggunaan Program Aplikasi:

1. Program aplikasi bisa dijalankan melalui localhost apabila sebelumnya pada komputer sudah ter-instal MySQL server. Untuk melakukan proses instalasi pengguna dapat menggunakan Xampp 1.6. 
2. Copy seluruh file aplikasi ke dalam folder C:|xamppไhtdocs\pohon.

3. Buka file aplikasi menggunakan Macromedia Dreamweaver, kemudian user dapat menekan tombol F12 pada keyboard untuk menjalankan aplikasi di dalam web browser.

4. Untuk membuka tampilan Map View pengguna terlabih dahulu harus terhubung dengan internet.

5. Pada penggunaan lebih lanjut, aplikasi ini dapat diposting di internet untuk digunakan secara online.

\section{Pembahasan}

\section{Inventarisasi Pohon dalam MySQL, Php, dan Google Map}

Dalam inventarisasi pohon ini, MySQL adalah aplikasi yang digunakan untuk menyimpan data. Pemasukkan data ini tidak langsung menggunakan MySQL, tetapi menggunakan aplikasi inventarisasi pohon yang telah dibuat dengan menggunakan Bahasa pemrograman Php. Data pohon yang dimasukkan yaitu nama lokal, nama latin, nama jalan, nama kota, id pohon, DBH, lebar tajuk, tinggi pohon, kerusakan HPT, kerusakan mekanik, dan bentuk tajuk, foto, latitude, dan longitude.

Pendataan nama spesies dilakukan dalam nama latin dan nama lokal, hal ini dilakukan untuk mempermudah identifikasi pohon baik oleh petugas, warga lokal, maupun akademisi dalam mencari informasi.

Pendataan ukuran pohon dilakukan pada diameter batang, tinggi pohon dan lebar tajuk. Data diameter batang dapat digunakan untuk menentukan usia pohon dan juga sebagai bahan perhitungan stok karbon yang ada pada pohon tersebut. Data tinggi pohon dan lebar tajuk diambil untuk melakukan perencanaan pemotongan tajuk dan dahan pohon.

Pendataan kerusakan pohon dilakukan berdasarkan standar yang dipakai oleh dinas pertamanan. Variabel kerusakan pohon yang didata dibagi berdasarkan dua tipe kerusakan, yaitu kerusakan yang disebabkan hama penyakit tanaman dan kerusakan yang disebabkan oleh proses mekanik. Inventarisasi kerusakan pohon dilakukan dangan pengamatan secara visual. 
Pengambilan data lokasi pohon antara lain mengambil data nama jalan, nama kota, dan juga koordinat. Data nama jalan dan nama kota diambil untuk memudahkan dalam proses pencarian data, terutama bila sistem ini sudah digunakan untuk menyimpan data pohon kota-kota di Indonesia.

Pengambilan foto pohon kota dilakukan dengana kamera dijital. Komposisi gambar pohon harus dapat menunjukkan seluruh bagian pohon. Fungsi dari pengambilan data foto adalah untuk melakukan pengecekan kondisi pohon. Selain itu, juga dapat mengetahui kondisi lingkungan sekitar pohon tersebut. Untuk itu data foto harus memiliki resolusi dan pencahayaan yang baik.

Penggunaan aplikasi MySQL dan Php pada pembuatan aplikasi ini dikarenakan keunggulan aplikasi yang dapat menyimpan data yang tidak terbatas sehingga dapat digunakan untuk penggunaan yang lebih luas yaitu menyimpan data pohon di seluruh kota di Indonesia.

Aplikasi inventarisasi pohon ini dibuat menggunakan bahasa pemrograman Php dengan Macromedia Dreamweaver sebagai alat bantu GUI. Tampilan dibuat menarik dan mudah untuk digunakan oleh pengguna/user. tampilan menarik karena didukung dengan penggunaan warna, tulisan, form dan kontrol yang sesuai. Apabila pengguna ingin memasukkan data, penggguna dapat masuk ke dalam form input data, selain itu user tidak perlu menghitung kerusakan pohon secara manual karena pada form input data pohon sudah tersedia fasilitas untuk menghitung kerusakan.

Pada tampilan map view pangguna dapat melihat kondisi pohon secara spasial dengan memanfaatkan layanan Googlemap, mode tampilan terbagi menjadi tiga yaitu map, satellite, dan hybrid. User interface yang digunakan untuk mode peta ini disesuaikan dengan user interface Googlemap. Metode spasial yang digunakan adalah dengan menggunakan data peta yang berasal dari layanan Google, kemudian data lokasi pohon yang berasal dari hasil pengambilan lapang digabungkan dengan Google Map API sehingga dapat dimunculkan pada posisi layer paling atas tampilan Google Map. Pada tampilan Map View terdapat fasilitas untuk melihat kondisi spasial dengan foto udara. Fasilitas foto udara dapat memudahkan pengelola untuk mengetahui kondisi sekitar pohon tersebut. Selain itu, tampilan foto udara juga dapat mempermudah fungsi-fungsi pengawasan 
pohon seperti melihat kondisi lebar tajuk pohon, melihat apakah ada pohon yang tumbang, apakah ada bangunan yang letaknya terlalu dekat dengan pohon, dan sebagainya.

Data Google $\quad$ Data input

Data Atribut dan data GPS

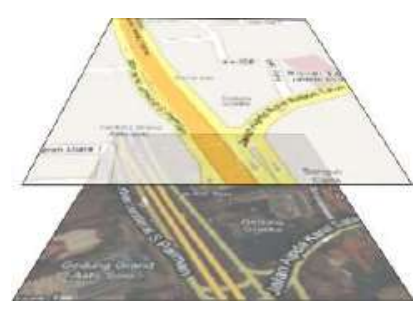

\begin{tabular}{|l|l|l|}
\hline Data atribut & lat & long \\
\hline & & \\
\hline & &
\end{tabular}

Googlemap API
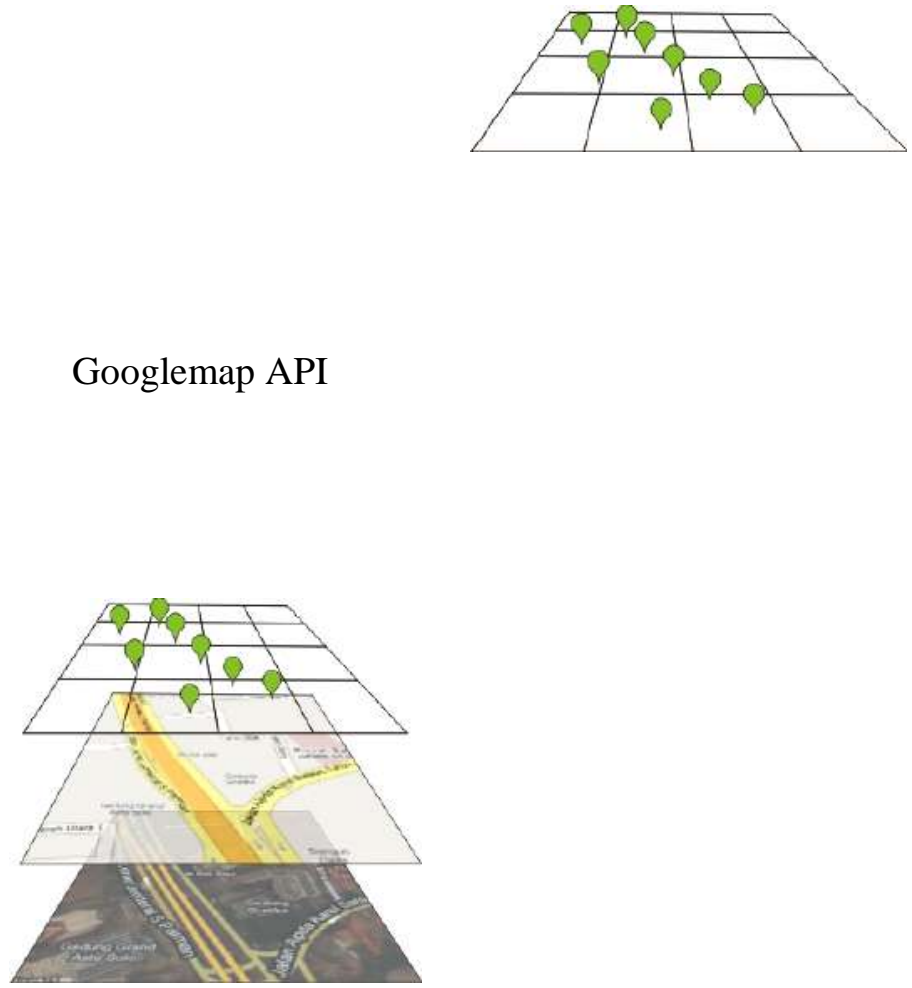

Gambar 20. Skema Proses Spasial 
Hasil pengambilan sampel data pohon di lapangan, yaitu pada jalan Palmerah Utara dan jalan S. Parman segmen Jembatan Slipi sampai Slipi Jaya kota Jakarta. Tercatat jumlah pohon masing-masing 73 dan 107 pohon. Pada kedua jalan kondisi kesehatan pohon seluruhnya sangat baik. Bentuk tajuk pohon pada jalan Palmerah Utara terdapat 48 pohon asimetris, sedangkan pada jalan S Parman terdapat 33 pohon asimetris. Data inventarisasi pohon selengkapnya terdapat pada lampiran dua.

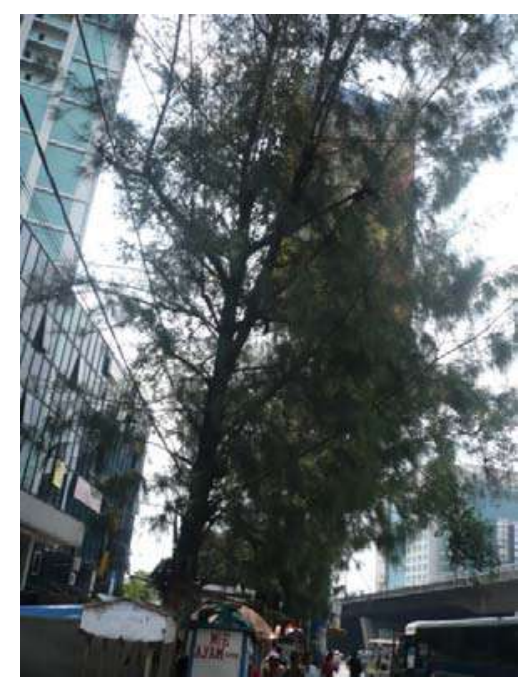

Gambar 21. Foto Salah Satu Pohon di Jalan S Parman

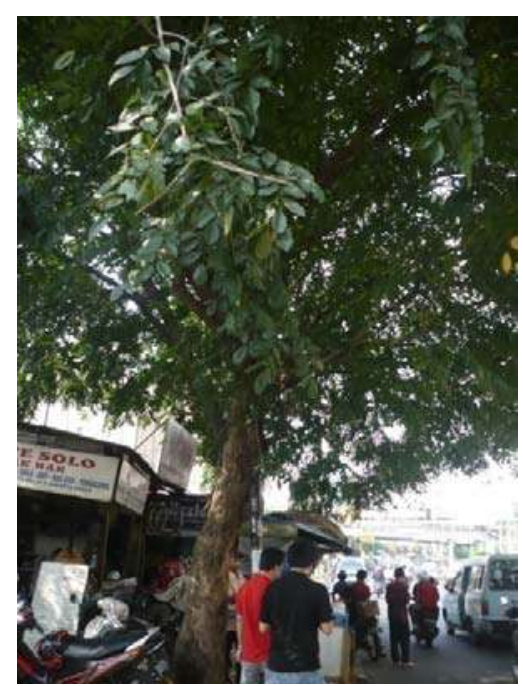

Gambar 22. Foto Salah Satu Pohon di Jalan Palmerah Utara 


\section{Inventarisasi Pohon untuk Instansi}

Instansi yang mengurus pohon, misalnya Dinas Pertamanan, pada umumnya memiliki tugas menyusun data inventarisasi pohon. Inventarisasi pohon ini bertujuan untuk memudahkan dalam penyusunan jadwal pemeliharaan. Data inventarisasi pohon yang dibuat berisi deskripsi pohon, kesehatan, jumlah, dan lokasi pohon yang terdapat di sepanjang jalan, sehingga bisa diketahui secara pasti perubahan jenis, kesehatan, dan jumlah pohon di lapangan. Pekerjaan membutuhkan tenaga dan biaya yang cukup besar, serta tidak dapat dilaksanakan dengan cepat. Selama ini pengelolaan data inventarisasi pohon dilakukan secara manual, sehingga apabila terjadi perubahan jenis, kesehatan, dan jumlah pohon di lapangan, memerlukan pemutakhiran yang dilampirkan, kemudian dilakukan pencetakan ulang. Cara seperti ini menyebabkan pengelola membutuhkan biaya besar dan waktu yang lama. Padahal dinamika perubahan pohon-pohon yang disebabkan oleh proses alami maupun akibat aktivitas perencanaan/perancangan lanskap bisa saja terjadi dalam waktu singkat. Hal ini membuat instansi seperti Dinas Pertamanan memerlukan aplikasi inventarisasi pohon. Disamping itu juga akan menghemat tenaga maupun biaya.

Hasil data inventarisasi secara dijital bisa digunakan pula untuk mempermudah penentuan biaya yang akan digunakan untuk pengelolaan dilihat dari kondisi pohon, keadaan tajuk, dan bisa dilihat dari foto yang terlampir, sehingga apabila terdapat keusakan yang sekiranya dapat membahayakan para pengguna jalan dapat dilakukan penanganan yang lebih lanjut. Misalkan terdapat cabang pohon yang dapat dilakukan tindakan pemotongan. Biaya pemotongan cabang pohon ini ditentukan oleh instansi yang bertanggung jawab atas pemeliharaan pohon masing-masing daerah.

Penggunaan Google Map sebagai dasar pendataan spasial juga memungkinkan pengembangan penggunaan aplikasi kearah yang lebih luas. Hal ini disebabkan database peta Google Map yang terus menerus diperbarui, sehingga pihak pengelola tidak perlu lagi melakukan update data peta secara manual. Selain itu data Google Map mencakup seluruh kota di Indonesia sehingga aplikasi ini sudah siap digunakan untuk mendata pohon di seluruh kota-kota di Indonesia. 


\section{KESIMPULAN DAN SARAN}

\section{Kesimpulan}

Penyusunan aplikasi basis data pohon memudahkan pengguna untuk melakukan inventarisasi pohon. Selain itu juga dapat dengan mudah mengetahui posisi dan informasi mengenai pohon tersebut dengan cepat, baik informasi fisiologi dan kerusakan pohon. Sehingga aplikasi inventarisasi pohon ini dapat mempercepat dan mempermudah pengelolaan dan pemeliharaan pohon, karena untuk mengelola pohon dengan skala pengelolaan yang sangat luas seperti kota besar maka instansi pengelola harus menyiapkan logistik dan anggaran yang cukup besar. Dengan adanya sistem pengelolaan basis data pohon secara digital maka pihak pengelola dapat secara cepat mendapatkan data tentang kondisi dan lokasi pohon pada suatu kota, hal ini memudahkan pengelola untuk menentukan anggaran biaya dan logistik yang dibutuhkan untuk pengelolaan pohon.

Penyusunan basis data pohon untuk tampilannya dibuat menggunakan bahasa pemrograman Php dengan Macromedia Dreamweaver 8 sebagai alat bantu GUI, sedangkan untuk menyimpan data atribut digunakan MySQL. Data atribut pohon dimasukkan melalui tampilan yang telah dibuat menggunakan Php. Untuk menampilkan kondisi spasial pohon digunakan aplikasi Google Map yang telah dikoneksikan kedalam aplikasi basis data pohon menggunakan Google Map API key. Pada tampilan spasial Google Map terdapat tampilan foto udara yang dapat memudahkan pengelola mengawasi pohon kota dan juga kondisi lingkungan sekitar pohon kota tersebut.

Tampilan akhir basis data ini berupa aplikasi web, sehingga untuk menjalankan aplikasi ini dibuhkan web browser dan juga koneksi internet. Untuk penggunaan lebih lanjut aplikasi ini dapat di-hosting dan dijalankan secara online. Keuntungan dari pembuatan aplikasi dengan sistem online adalah kemudahan akses dari sistem ini, sistem basis data pohon memungkinkan akses dari berbagai tempat. 


\section{Saran}

Pada pembuatan aplikasi ini masih banyak kekurangan yang membuat aplikasi ini belum cukup aman untuk diterapkan secara online karena pada aplikasi ini belum terdapat sistem keamanan yang cukup baik. Untuk itu perlu di lakukan pemasangan sistem keamanan sebelum sistem ini di jalankan

Tampilan yang dibuat dengan menggunakan Php dapat dimodifikasi menjadi tampilan yang lebih menarik dan interaktif, sehingga pengguna dapat lebih mudah menggunakannya. Untuk itu diperlukan penyempurnaan pada penelitian selanjutnya. Selain itu pada penelitian ini yang digunakan adalah Google Map API versi gratis sehingga tidak terdapat pembaruan tampilan aerial tiap hari dan juga perbesaran yang terbatas. Untuk itu apabila sistem ini akan diaplikasikan pada instansi pengelola pohon sebaiknya Google Map API yang digunakan adalah versi berbayar.

Pada tahap pengambilan data spasial terdapat hambatan yaitu akurasi alat yang digunakan, sehingga menyebabkan beberapa titik koordinat pohon tidak sesuai dengan lokasi sebenarnya. Untuk itu diperlukan GPS dengan akurasi yang cukup tajam apabila sistem ini akan diaplikasikan pada instansi pengelola. Selain itu kondisi cuaca juga mempengaruhi hasil pendataan, pengambilan data akan memiliki akurasi lebih baik apabila diambil pada kondisi cuaca cerah.

Secara aplikasi, sistem ini dapat dikembangkan lebih luas lagi dengan menambahkan fungsi-fungsi penilaian nilai ekologis dari pohon kota di Indonesia. Hal ini tentunya terkait dengan adanya basis data penelitian yang lengkap terhadap kemampuan jenis - jenis pohon di Indonesia dalam menyerap polusi, menyerap air, menurunkan suhu, dsb.

Metode yang digunakan dalam penelitian ini dapat terus dikembangkan pada berbagai aspek lainnya. Karena pendataan basis data secara spasial sangat membantu dalam berbagai bidang ilmu dalam aspek pengelolaan, analisis, promosi, dan penyampaian informasi. 


\section{DAFTAR PUSTAKA}

Arifin, H. S. A dan Nurhayati. 2000. Pemeliharaan Taman. Penebar Swadaya. Jakarta.

Aziz, M dan S. Pujiono. 2006. Sistem Informasi Geografis Berbasis Desktop dan Web. Penerbit Gava Media. Yogyakarta.

Carpenter. P. L. T. D Walker, and F. O. Lanphear. 1975. Plant in Landscape. W.H.Freeman And Company. San Fransisco.

Lestari, Garsinia dan I.P. Kencana. 2008. Galeri Tanaman Hias Lanskap. Penebar Swadaya. Jakarta.

Kadir, Al. 2010. From Zero to Hero Membuat Aplikasi Web Dengan PHP + Database MySQL. Penerbit Andi. Yogyakarta.

Kompas.2010.http://megapolitan.kompas.com/read/2010/10/09/08544836/Kalima lang.Padat.Akibat.Pohon.Tumbang. Diakses 10 November 2010.

Pemerintah Indonesia. 1980. Undang -undang Republik Indonesia Nomor 13. Departemen Pekerjaan Umum. Direktorat Jendral Bina Marga.

Pimpler, E. 2007. Mashup Mania with Google Maps. GeoSpatial Training Services, LLC. San Antonio.

Simonds, J. O. 1983 Landscape Architecture. Mc Graw Hill Book Co. New York.

Sulistyantara, B., I. W. Hidayat, A. N. Taher, Isdiyantoro, A. Kastolani. 2006. Pembangunan Sistem Informasi Manajemen RTH Taman Dan Jalur Hijau Wilayah Kotamadya Jakarta Timur. Departemen Arsitektur Lanskap Fakultas Pertanian Instutut Pertanian Bogor. Bogor.

Tim Divisi Pengelitian dan Pengembangan MADCOMS. 2008. Aplikasi Web Database Menggunakan Dreamweaver CS3 dan Pemrograman PHP + MySQL. Penerbit Andi, Yogyakarta.

Wood, P. J. 1999. Tree Inventories and GIS in Urban Forestry. Faculty of theVirginia Polytechnic Institute and State University. Virginia. 


\section{Lampiran 1. Data Inventarisasi Pohon}

Keterangan

Kerusakan Hama Penyakit:

Akar dan batang (HPT A):

1. Tumbuhan tidak bukan parasit

2. Tumbuhan parasit

3. Batang kering/lapuk, akar kering/ lapuk

4. Batang busuk, akar busuk

5. Gerowong (keropos yang tampak pada batang utama

Cabang dan daun (HPT B):

1. Tumbuhan tidak parasit

2. Tumbuhan parasit

3. Klorosis

4. Nekrosis

5. Percabangan lapuk

Kerusakan Mekanik

1. Corat-coret/ reklame

2. Goresan

3. Sayatan

4. Patah cabang

5. Tersambar petir 


\section{Lampiran 2. Coding Pada Form Aplikasi}

\section{Form Login, pada Form Login ditulis kode program sebagai berikut:}

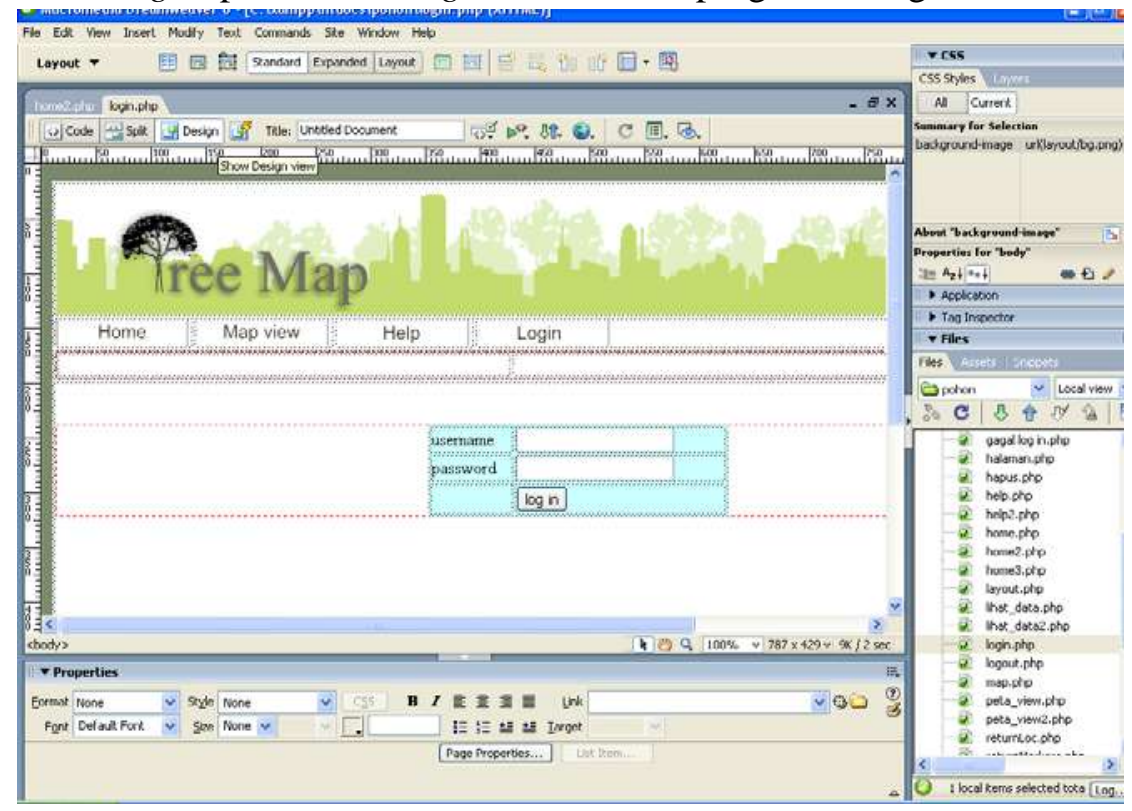

$<$ ?php require_once('Connections/sql.php'); ?>

$<$ ?php

mysql_select_db(\$database_sql, \$sql);

\$query_login = "SELECT * FROM pass";

\$login = mysql_query $($ \$query_login, \$sql) or die(mysql_error());

\$row_login = mysql_fetch_assoc $($ \$login $)$;

\$totalRows_login = mysql_num_rows(\$login);

?>

$<$ ?php

//*** Validate request to login to this site.

if (!isset(\$_SESSION)) \{

session_start();

\}

\$loginFormAction = \$_SERVER['PHP_SELF'];

if (isset(\$_GET['accesscheck'])) \{

\$_SESSION['PrevUrl'] = \$_GET['accesscheck'];

\}

if (isset(\$_POST['username'])) \{

\$loginUsername=\$_POST['username'];

\$password=\$_POST['password'];

\$MM_fldUserAuthorization = "';

\$MM_redirectLoginSuccess = "home3.php";

\$MM_redirectLoginFailed = "gagal log in.php";

\$MM_redirecttoReferrer = false;

mysql_select_db(\$database_sql, \$sql);

\$LoginRS_query=sprintf("SELECT user_id, pswrd FROM pass WHERE user_id='\%s'

AND pswrd='\%s'",

get_magic_quotes_gpc() ? \$loginUsername : addslashes(\$loginUsername), get_magic_quotes_gpc() ? \$password : addslashes(\$password)); 


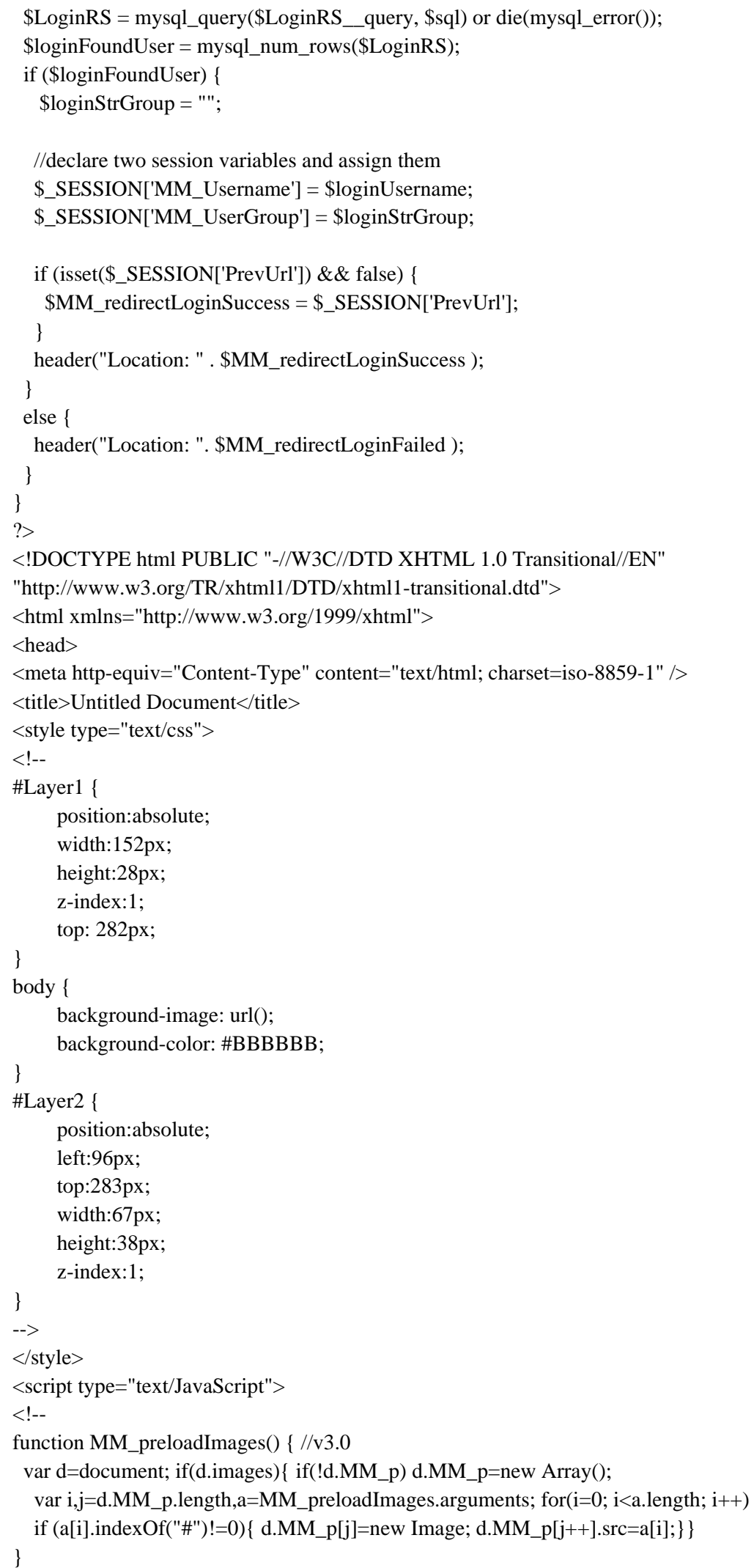


function MM_findObj(n, d) \{ //v4.01

var p,i,x; if(!d) d=document; if((p=n.indexOf("?"))>0\&\&parent.frames.length) \{ $\mathrm{d}=$ parent.frames[n.substring( $\mathrm{p}+1)]$.document; $\mathrm{n}=\mathrm{n}$.substring $(0, \mathrm{p}) ;\}$ if $($ ! $(x=d[n]) \& \& d . a l l) x=d . a l l[n]$; for $(i=0 ; ! x \& \& i<$ d.forms.length;i++) $x=d . f o r m s[i][n]$; for $(\mathrm{i}=0 ;$ ! $\mathrm{x} \& \& d$.layers\&\& $\mathrm{i}<$ d.layers.length; $\mathrm{i}++) \mathrm{x}=\mathrm{MM}$ _findObj(n,d.layers[i].document); if(!x \&\& d.getElementById) x=d.getElementById(n); return x;

\}

2. Pada Form Home, pada Form Home ditulis kode program sebagai berikut:

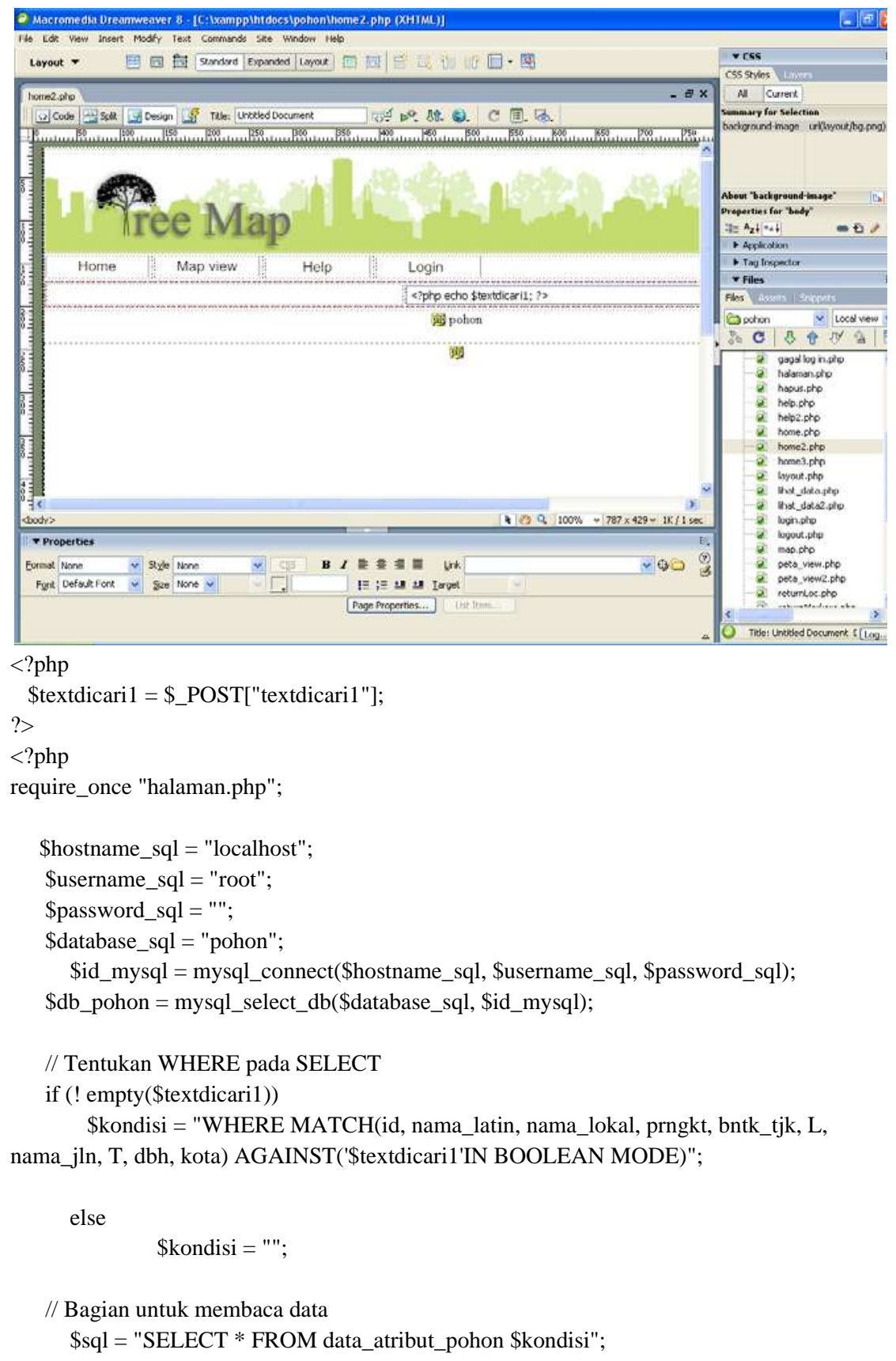




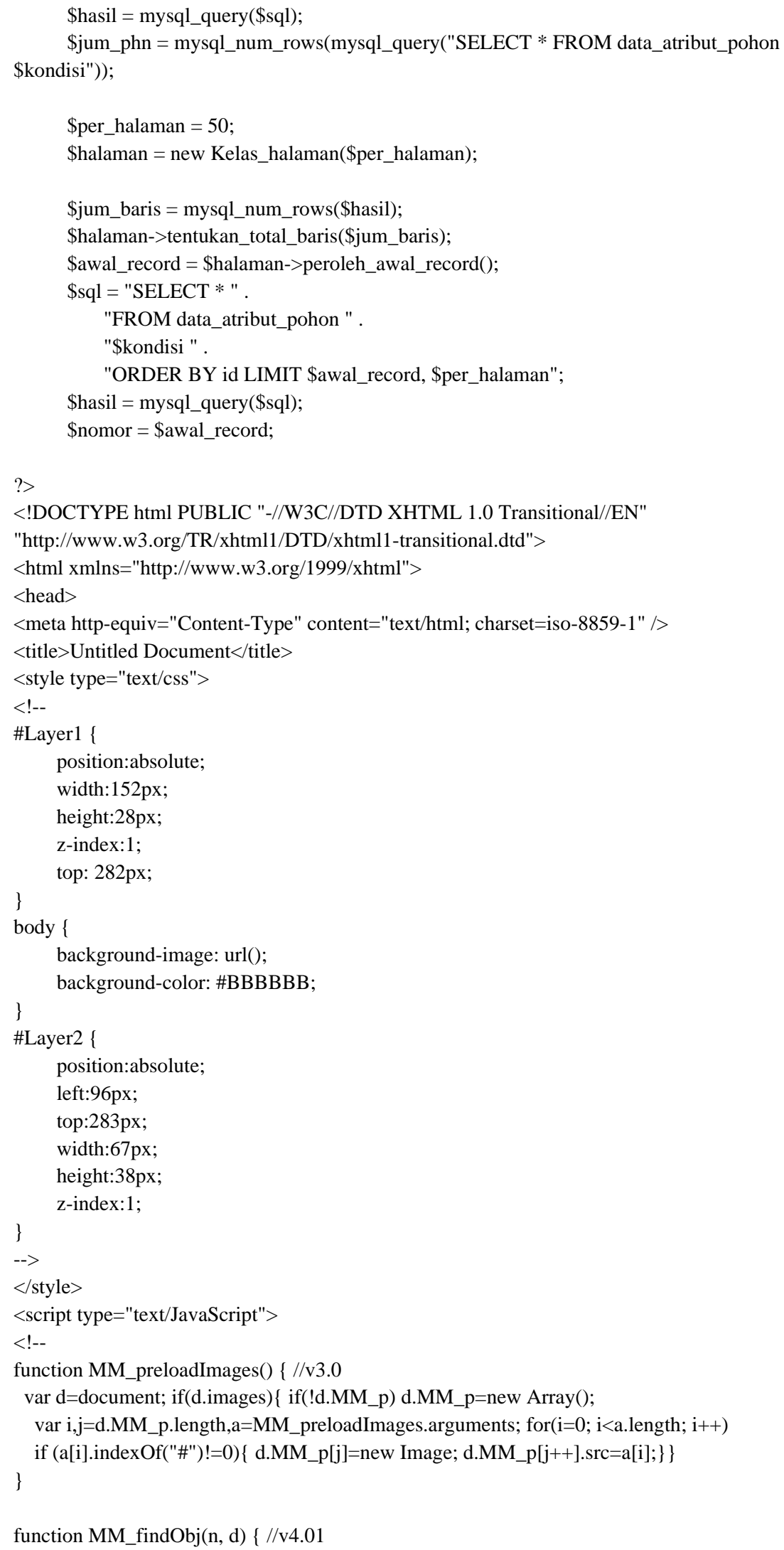


var p,i,x; if(!d) d=document; if((p=n.indexOf("?"))>0\&\&parent.frames.length) \{ $\mathrm{d}=$ parent.frames[n.substring(p+1)].document; $\mathrm{n}=\mathrm{n}$.substring $(0, \mathrm{p}) ;\}$ if $(!(x=d[n]) \& \& d . a l l) x=d . a l l[n]$; for $(i=0 ; ! x \& \& i<$ d.forms.length;i++) $x=$ d.forms [i] [n]; for(i=0;!x\&\&d.layers\&\&i<d.layers.length;i++) $\mathrm{x}=\mathrm{MM} \_$findObj(n,d.layers[i].document); if(!x \&\& d.getElementById) x=d.getElementById(n); return x; \}

3. Form Input Data, pada Form Input Data ditulis kode program sebagai berikut:

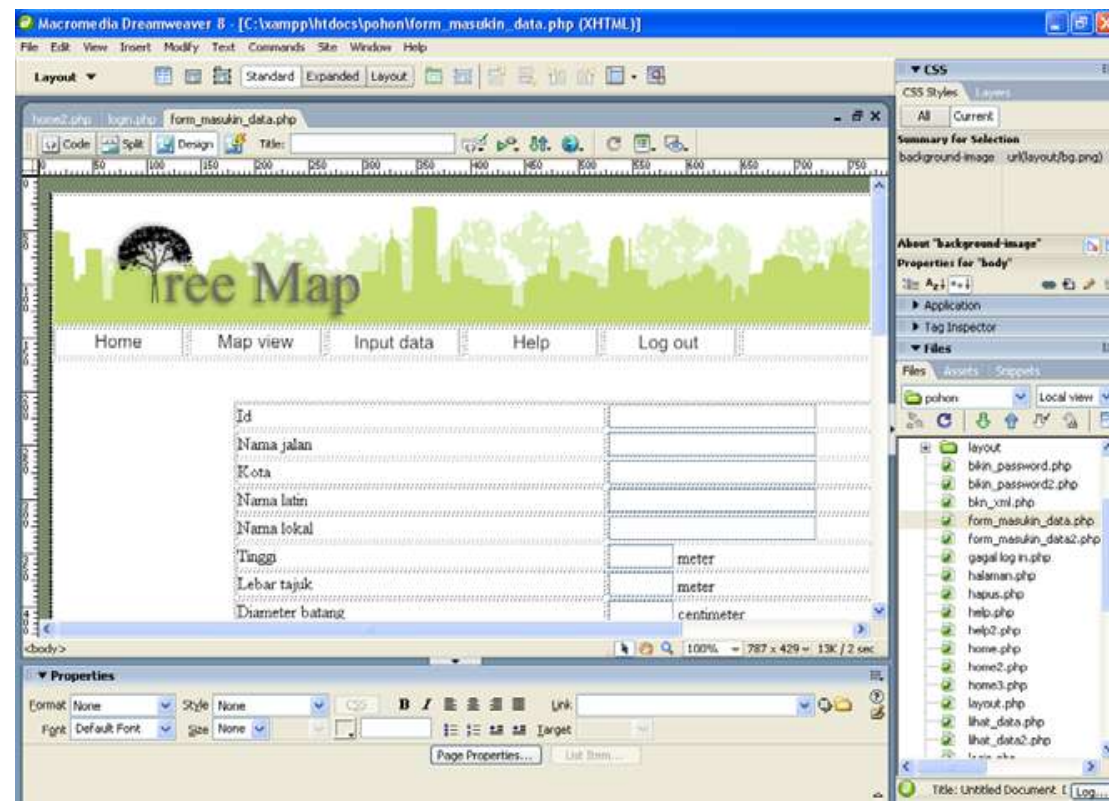

$<$ !DOCTYPE html PUBLIC "-//W3C//DTD XHTML 1.0 Transitional//EN"

"http://www.w3.org/TR/xhtml1/DTD/xhtml1-transitional.dtd">

$<$ html xmlns="http://www.w3.org/1999/xhtml">

$<$ head $>$

$<$ meta http-equiv="Content-Type" content="text/html; charset=iso-8859-1" />

$<$ title $>$

$<$ MMString:LoadString id="insertbar/formsCheckbox" />

$</$ title $>$

$<$ !-- Copyright 2000, 2001, 2002, 2003 Macromedia, Inc. All rights reserved. -->

$<$--- Copyright 2000, 2001, 2002, 2003 Macromedia, Inc. All rights reserved. -->

$<$ style type="text/css">

$<!--$

body \{

background-color: \#BBBBBB;

\}

$<$ /style $>$

$<$ script type="text/JavaScript" $>$

$<!--$

function MM_preloadImages() \{ //v3.0

var d=document; if(d.images) \{ if(!d.MM_p) d.MM_p=new Array(); var i,j=d.MM_p.length,a=MM_preloadImages.arguments; for $(\mathrm{i}=0$; $\mathrm{i}<\mathrm{a}$.length; $\mathrm{i}++)$ if (a[i].indexOf("\#")!=0)\{ d.MM_p[j]=new Image; d.MM_p[j++].src=a[i];\}\} 
function MM_findObj(n, d) \{ //v4.01

var p,i,x; if(!d) d=document; if((p=n.indexOf("?"))>0\&\&parent.frames.length) \{ $\mathrm{d}=$ parent.frames[n.substring( $\mathrm{p}+1)]$.document; $\mathrm{n}=\mathrm{n} . \operatorname{substring}(0, \mathrm{p}) ;\}$

if $($ ! $(x=d[n]) \& \& d . a l l) x=d . a l l[n]$; for $(\mathrm{i}=0 ; ! x \& \& \mathrm{i}<$ d.forms.length;i++) $\mathrm{x}=\mathrm{d}$. forms [i][n]; for(i=0;!x\&\&d.layers\&\&i<d.layers.length;i++) $\mathrm{x}=\mathrm{MM} \_$findObj(n,d.layers[i].document); if(!x \&\& d.getElementById) x=d.getElementById(n); return x; \}

function MM_nbGroup(event, grpName) \{ //v6.0

var i,img,nbArr,args=MM_nbGroup.arguments;

if (event == "init" \&\& args.length $>2)\{$

if ((img = MM_findObj(args[2])) != null \&\& !img.MM_init) \{

img.MM_init = true; img.MM_up = args[3]; img.MM_dn = img.src;

if $((\mathrm{nb} A r r=$ document[grpName] $)==$ null $)$ nbArr = document[grpName] = new Array () ;

nbArr[nbArr.length] = img;

for (i=4; i < args.length-1; i+=2) if ((img = MM_findObj(args[i])) != null) \{

if (!img.MM_up) img.MM_up = img.src;

img.src = img.MM_dn = args $[i+1]$;

nbArr[nbArr.length] = img;

\} \}

\} else if (event == "over") \{

document.MM_nbOver $=$ nbArr $=$ new Array () ;

for (i=1; i < args.length-1; i+=3) if ((img = MM_findObj(args[i])) != null) \{

if (!img.MM_up) img.MM_up = img.src;

img.src = (img.MM_dn \&\& args[i+2]) ? args[i+2] : ((args[i+1]) args[i+1] : img.MM_up); nbArr[nbArr.length] = img;

\}

4. Form Detail, pada Form Detail ditulis kode program sebagai berikut:

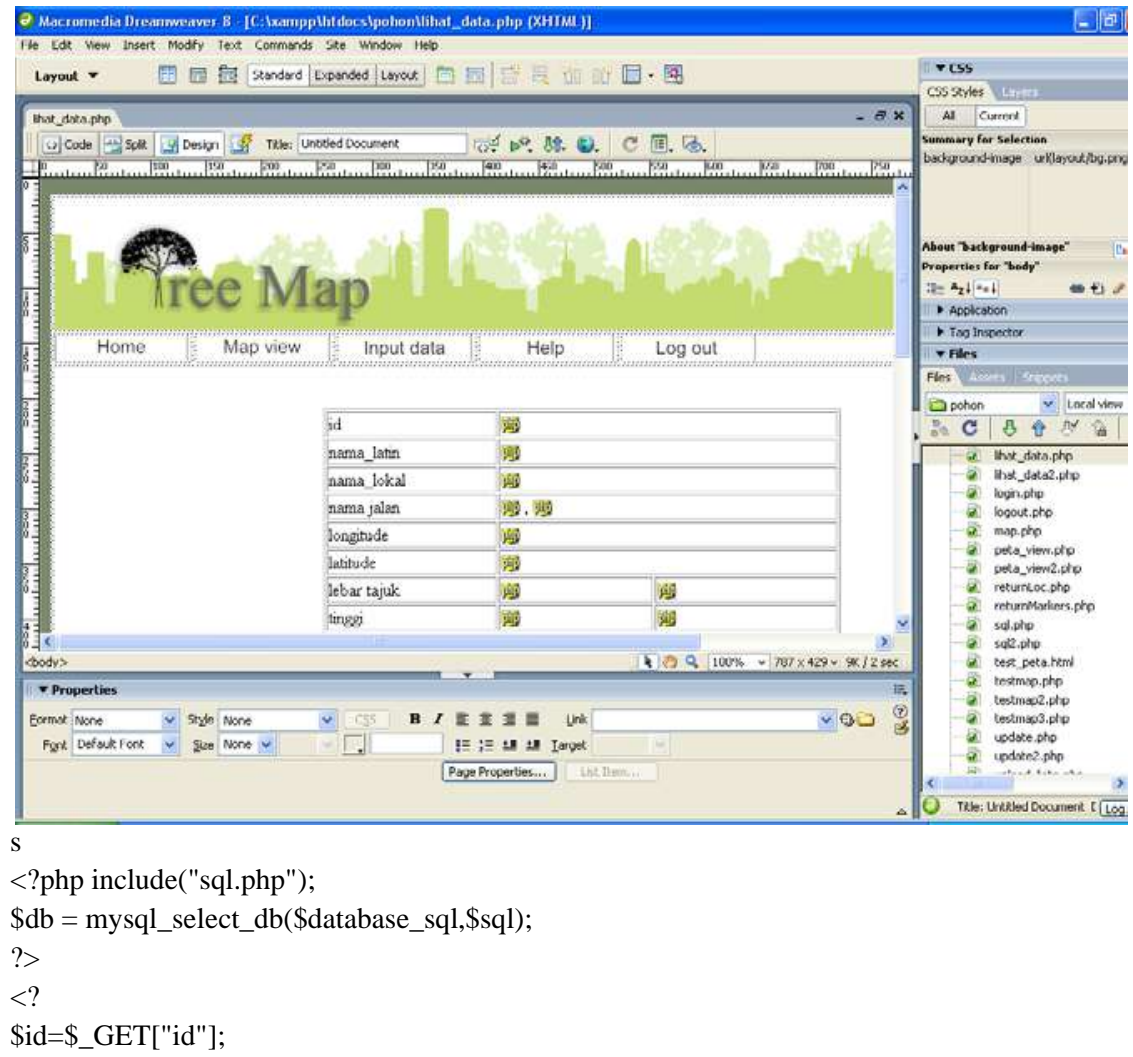


\$show_query=mysql_query("select * from data_atribut_pohon where id = '\$id"');

\$show_detail=mysql_fetch_array(\$show_query);

\$id_pohon="\$show_detail[id]";

\$nama_latin="\$show_detail[nama_latin]";

\$nama_lokal="\$show_detail[nama_lokal]";

\$latitude="\$show_detail[latitude]";

\$longitude="\$show_detail[longitude]";

\$gmbr="\$show_detail[foto]";

\$nm_jln ="\$show_detail[nama_jln]";

\$lbr_tjk ="\$show_detail[lebar_tjk]";

\$tinggi ="\$show_detail[tinggi]";

\$diameter ="\$show_detail[diameter]";

\$bntk_tjk ="\$show_detail[bntk_tjk]";

\$hpta = "\$show_detail[hpta]";

\$hptb = "\$show_detail[hptb]";

\$mknk = "\$show_detail[mknk]";

\$total = "\$show_detail[total]";

\$prngkt = "\$show_detail[prngkt]";

\$dbh = "\$show_detail[dbh]";

$\$ \mathrm{~L}=$ "\$show_detail[L]";

\$T = "\$show_detail[T]";

\$kota = "\$show_detail[kota]";

?>

$<$ !DOCTYPE html PUBLIC "-//W3C//DTD XHTML 1.0 Transitional//EN"

"http://www.w3.org/TR/xhtml1/DTD/xhtml1-transitional.dtd">

$<$ html xmlns="http://www.w3.org/1999/xhtml">

$<$ head $>$

$<$ meta http-equiv="Content-Type" content="text/html; charset=iso-8859-1" / >

$<$ title $>$ Untitled Document $</$ title $>$

$<$ style type="text/css">

$<!--$

body \{

background-color: \#BBBBBB;

\}

$-->$

$</$ style $>$

$<$ script type="text/JavaScript" $>$

$<!--$

function MM_preloadImages() \{ //v3.0

var d=document; if(d.images $)\{$ if(!d.MM_p) d.MM_p=new Array();

var i,j=d.MM_p.length,a=MM_preloadImages.arguments; for $(\mathrm{i}=0$; $\mathrm{i}<\mathrm{a}$.length; $\mathrm{i}++)$

if (a[i].indexOf("\#")!=0)\{ d.MM_p[j]=new Image; d.MM_p[j++].src=a[i];\}\}

\}

function MM_findObj(n, d) \{ //v4.01

var p,i,x; if(!d) d=document; if((p=n.indexOf("?"))>0\&\&parent.frames.length) \{

$\mathrm{d}=$ parent.frames[n.substring(p+1)].document; $\mathrm{n}=\mathrm{n}$.substring $(0, \mathrm{p}) ;\}$

if $(!(x=d[n]) \& \&$ d.all $) x=$ d.all[n]; for $(i=0 ; ! x \& \& i<$ d.forms.length; $i++) x=d . f o r m s[i][n]$; for(i=0;!x\&\&d.layers\&\&i<d.layers.length;i++) $\mathrm{x}=\mathrm{MM} \_$findObj(n,d.layers[i].document);

if(!x \&\& d.getElementById) $x=$ d.getElementById(n); return $x$; 
5. Form Map View, pada Form Map View ditulis kode program sebagai berikut:

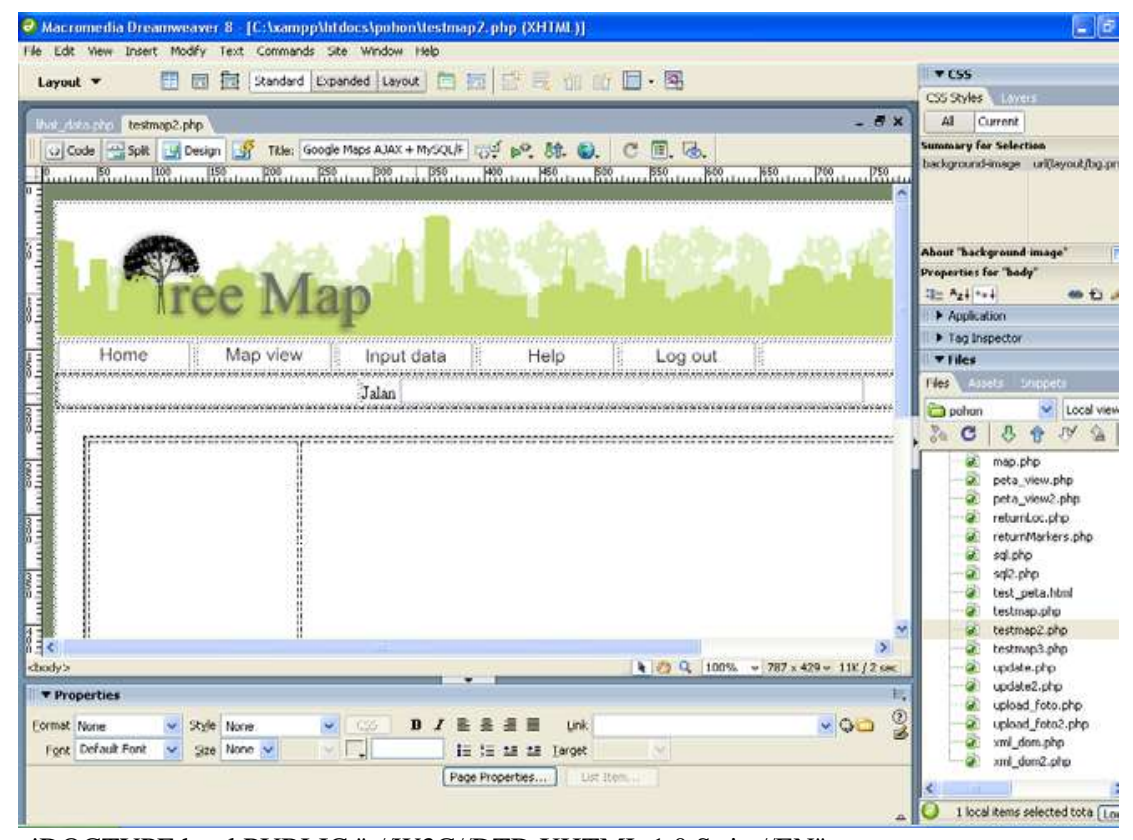

$<$ !DOCTYPE html PUBLIC "-//W3C//DTD XHTML 1.0 Strict//EN"

"http://www.w3.org/TR/xhtml1/DTD/xhtml1-strict.dtd">

$<$ html xmlns="http://www.w3.org/1999/xhtml">

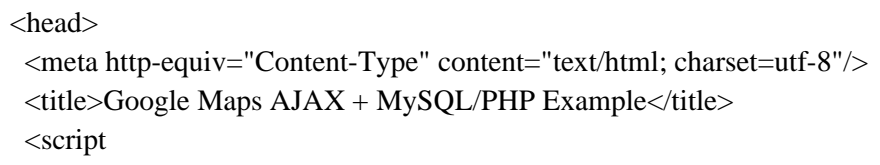




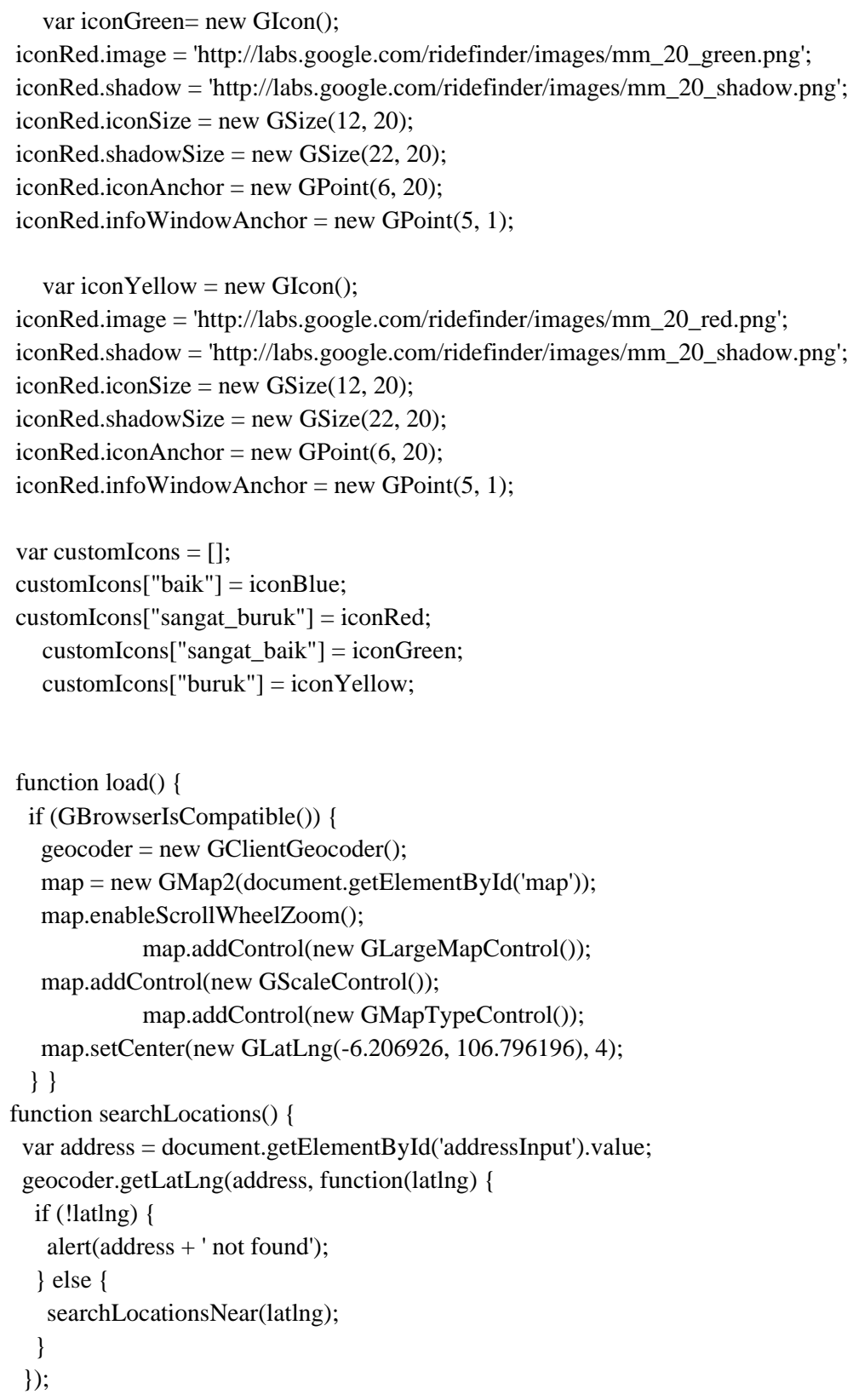


6. Pada Form Help, pada Form Help ditulis kode program sebagai berikut:

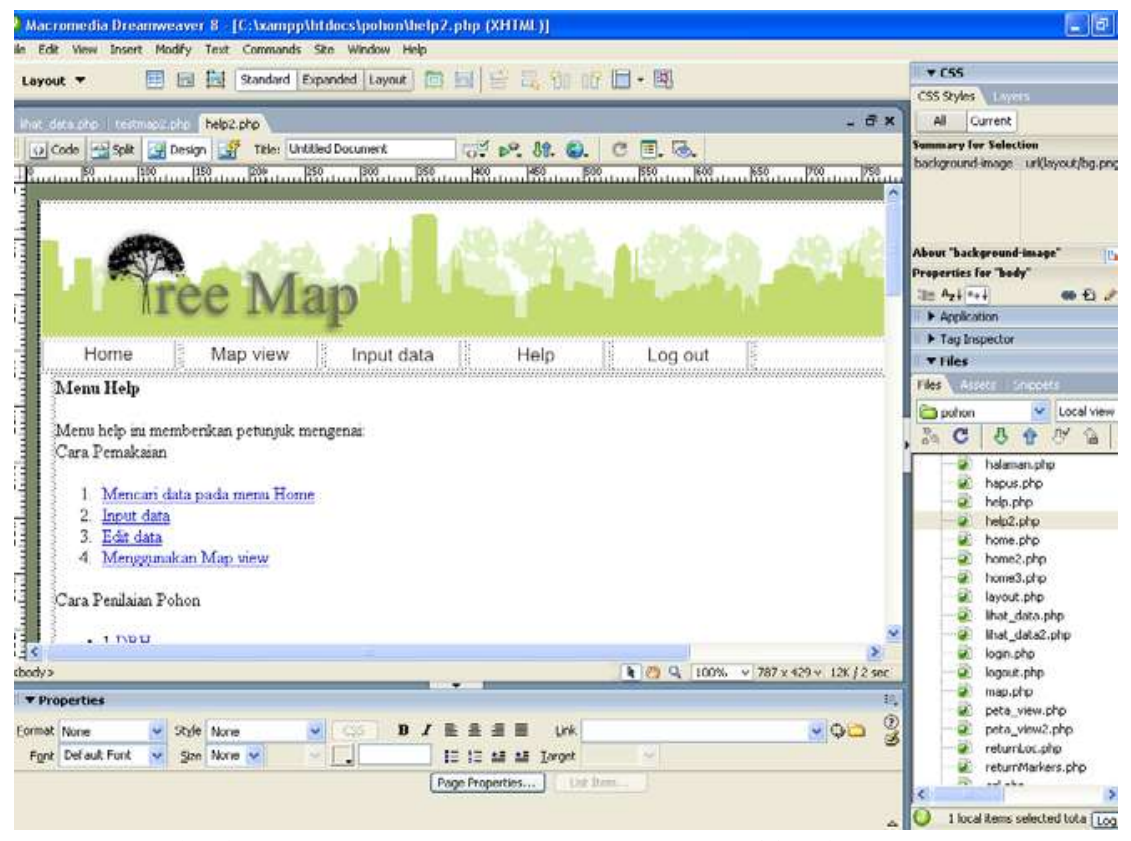

$<$ !DOCTYPE html PUBLIC "-//W3C//DTD XHTML 1.0 Transitional//EN"

"http://www.w3.org/TR/xhtml1/DTD/xhtml1-transitional.dtd">

$<$ html xmlns="http://www.w3.org/1999/xhtml">

$<$ head $>$

$<$ meta http-equiv="Content-Type" content="text/html; charset=iso-8859-1" />

$<$ title $>$ Untitled Document $</$ title $>$

$<$ style type="text/css">

$<!--$

\#Layer1 \{

position:absolute;

width:152px;

height:28px;

z-index:1;

top: 282px;

\}

body \{

background-image: url();

background-color: \#BBBBBB;

\}

\#Layer2 \{

position:absolute;

left:96px;

top:283px;

width:67px;

height:38px;

z-index:1;

\}

.style1 \{color: \#0080FF\}

.style2 \{color: \#0099FF\}

-->

$<$ /style $>$

$<$ script type="text/JavaScript" $>$ 


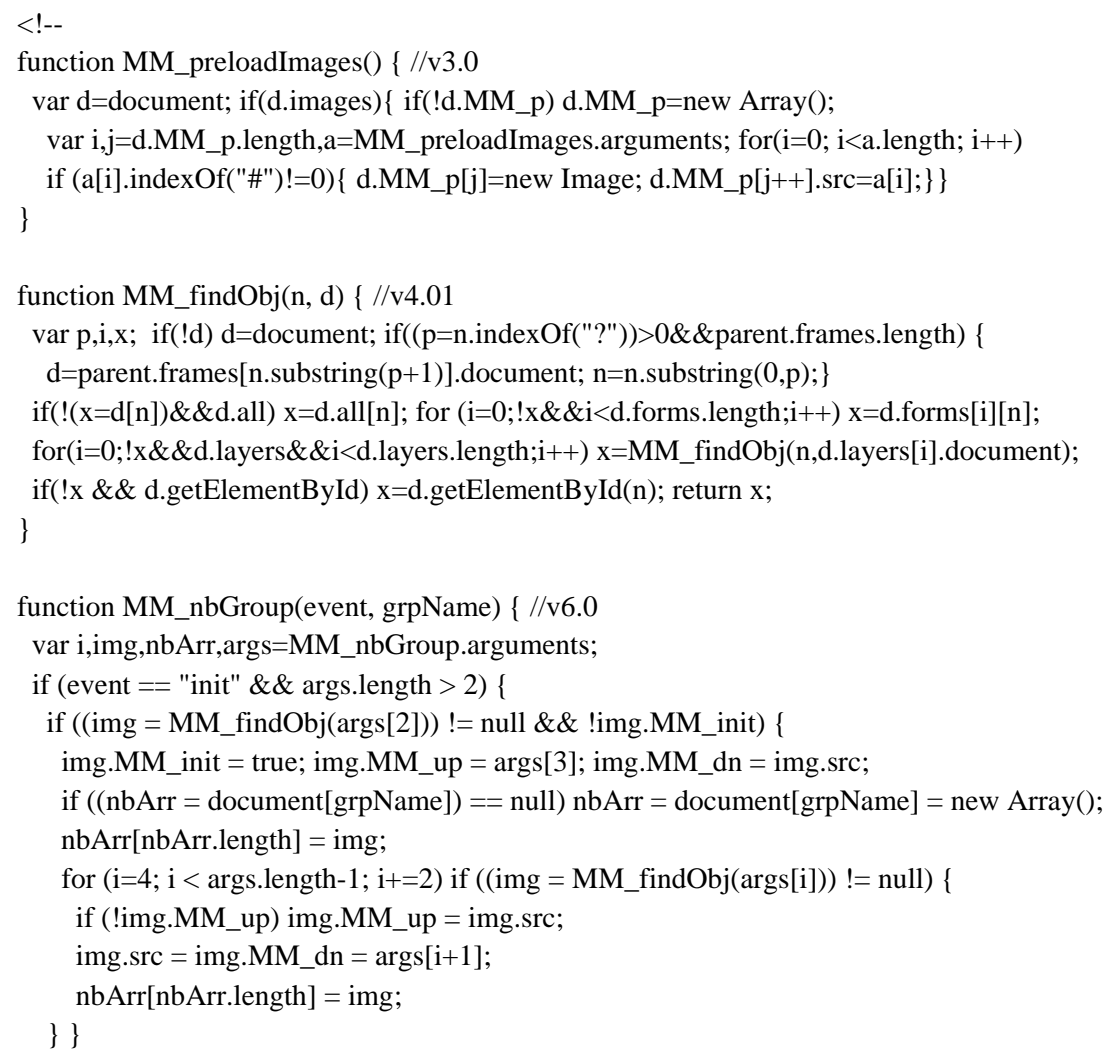

